\title{
Optimization of Hot Water Temperature Dipping and Calcium Chloride Treatment to the Selected Physico-Chemical Parameters of Keitt Mango and Cavendish Banana Fruits
}

\author{
Dovel Branquinho Ernesto ${ }^{1,2 *}$, Mary Omwamba², Abdul Faraj², Symon Mahungu ${ }^{2}$ \\ ${ }^{1}$ Agriculture Division of Instituto Superior Politécnico de Manica, Matsinho, Mozambique \\ ${ }^{2}$ Dairy \& Food Science \& Technology Department, Egerton University, Njoro, Kenya \\ Email: *ernestodovel@hotmail.com
}

How to cite this paper: Ernesto, D.B., Omwamba, M., Faraj, A. and Mahungu, S. (2017) Optimization of Hot Water Temperature Dipping and Calcium Chloride Treatment to the Selected Physico-Chemical Parameters of Keitt Mango and Cavendish Banana Fruits. Food and Nutrition Sciences, 8, 912-935. https://doi.org/10.4236/fns.2017.810066

Received: August 31, 2017

Accepted: October 10, 2017

Published: October 13, 2017

Copyright $\odot 2017$ by authors and Scientific Research Publishing Inc. This work is licensed under the Creative Commons Attribution International License (CC BY 4.0).

http://creativecommons.org/licenses/by/4.0/

\begin{abstract}
Mango (Mangifera indica L.) and banana (Musa acuminata) are the most popular fruits in the world and widely cultivated crops in the tropical and subtropical zones. Keitt mangoes and Cavendish bananas are the largest cultivar of these fruits found in the Mozambique market. They are only available for a short period each year mostly during the late summer and early falls. Due to mango and banana fruits high water activity and respiration rate, are perishable foods and require conservation methods for preservation and availability. The aim of this study was to optimize the hot water-calcium chloride concentration treatment regime for improved postharvest handling of mangoes and bananas. The fruits collected were of uniform size, and at greenyellowish maturity stage based on length, diameter, colour and firmness. The process was optimized by experimental central composite design using hot water temperature $\left(50^{\circ} \mathrm{C}-60^{\circ} \mathrm{C}\right)$ and calcium chloride concentration $(2 \%$ $4 \%)$ with the aid of desirability function. The samples were analyzed for the centesimal composition, firmness, colour, ${ }^{\circ} \mathrm{Brix}, \mathrm{A}_{\mathrm{w}}, \mathrm{pH}$, titratable acidity and vitamin $\mathrm{C}$. The results showed that hot water temperature and calcium chloride concentration were influent on the Keitt mangoes $\mathrm{b}^{*}$ colour attribute, $\mathrm{pH}$ and titratable acidity as well as the Cavendish bananas firmness, ash and vitamin $\mathrm{C}$ content. The optimal conditions of the process were stabilized with the desirable function and, coincidentally for both crops, obtained at $55^{\circ} \mathrm{C}$ of hot water temperature dipping and $3 \%$ of calcium chloride concentration. The simulated data were similar to the experimental ones. This is the first time that calcium chloride-hot water treatment is being reported as a means of extending the shelf-life of mangoes and bananas.
\end{abstract}




\section{Keywords}

Mangifera, Musa, Optimization, Central Composite Design, Desirability Function

\section{Introduction}

Mango (Mangifera indica L.) [1] and Banana (Musa acuminata) [2] are the most popular fruits in the world, and also, the most widely cultivated crops in the tropical and subtropical zones. There are several cultivars of these two fruits that come in different sizes, colour, weight and taste. Keitt mangoes are the largest cultivar of Mangifera indica seen in the Mozambique market [3]. They also are said to be some of the most flavourful and tangy mangoes available. Keitt mangoes are available for a short time during the late summer and early falls. Mango fruit [4] is rich in pre-biotic dietary fiber, vitamins, minerals, and poly-phenolic flavonoid antioxidant compounds. Mango fruit is an excellent source of Vitamin-A and flavonoids like beta-carotene, alpha-carotene, and beta-cryptoxanthin.

The Cavendish banana is the most widely-grown banana cultivar. The fruits of the Cavendish bananas are eaten raw, used in baking, fruit salads, compotes and to complement foods. The banana fruit is composed of a soft, easily digestible flesh, made up of simple sugars like fructose and sucrose. Bananas are also rich in health benefiting anti-oxidants, minerals, and vitamins. However, these fruits upon consumption, these sugars instantly replenish energy and revitalize the body [5] [6]. Due to its high water activity and respiration rate, it is a perishable food and requires conservation methods for preservation and availability [7].

In majority fleshy fruits like mango [8] and banana [9], physico-chemical characteristics are more important than other aromatic properties and fruit centesimal composition, firmness, colour, soluble solids, $\mathrm{pH}$, titratable acidity and vitamin $\mathrm{C}$ are some of them. Therefore, physico-chemical parameters perception is an important factor for quality evaluation of fruit and vegetable products and critical in determining the acceptability of fresh fruits [10]. Further, physico-chemical parameters of mango [11] [12] and banana [13] [14] had been reported to show variation with specific cultivars, maturity stage and postharvest treatment.

In recent years there has been growing interest in heat-treatments as a method of reducing chilling injury in fruits, and other horticultural crops, thus permitting extended storage times [15]. Heat treatment has been shown to be generally effective as a postharvest treatment on maintaining quality parameters in grapefruits [16] and also reducing chilling injury in tomato fruit [17] during cold storage. Tolerance to low temperature in 'Hass' avocado can be increased by pretreatment with high temperature such as $38^{\circ} \mathrm{C}$ hot air and hot water treatments [18]. It has been reported that heat treatment could protect the ultra-structure of 
the pericarp cells in the heat pre-treated dragon fruit under chilling stress [19].

Apart from heat treatment, other techniques such as calcium salts have also been used in the delay of climacteric fruits ripening process. Calcium chloride has shown promise in quality retention, firmness improvement and extends the postharvest shelf life of fruits and vegetables. Pre- and post-harvest application of calcium may help to reduce senescence during commercial and retail storage of fruit, with no detrimental effect on consumer acceptance [20]. Calcium chloride has been reported to reduce the onset of ripening in Atemoya [20] avocado [21] and strawberry [22].

Although hot water and calcium chloride as post-harvest losses reduction treatments and shelf-life prolong were already studied, reports on the effects of calcium chloride on the ripening and other physiological aspects in mangoes and bananas are scarce or totally missing. No work on the optimum hot water treatment in combination with calcium chloride concentration for improved postharvest storage of mango and banana fruits is published. Thus, the aim of this study was to optimize the hot water-calcium chloride concentration treatment regime for improved postharvest handling of Keitt mangoes and Cavendish bananas. It was also of interest to investigate the effects of the optimized hot water treatment and calcium chloride concentration on selected physico-chemical parameters: firmness, colour, centesimal composition, total soluble solids ( $\left.{ }^{\circ} \mathrm{Brix}\right)$, water activity $\left(\mathrm{A}_{\mathrm{w}}\right), \mathrm{pH}$, tritratable acidity $(\mathrm{TA})$ and vitamin $\mathrm{C}$ of mango and banana fruits. The process was optimized by experimental central composite design with the use of desirability function.

\section{Material and Methods}

\subsection{Material}

For this research work, the Keitt mango fruits were bought in Ribaue disctrict (Nampula Province in the north part of Mozambique) and the Cavendish banana fruits from local market of Macate district (Manica Province in the central part of Mozambique) where its geographical coordinates are $15^{\circ} 05^{\prime} 51^{\prime \prime}$ South, $38^{\circ} 23^{\prime} 22^{\prime \prime}$ East and $19^{\circ} 08^{\prime} 32^{\prime \prime}$ South, 33 $64^{\prime} 56^{\prime \prime}$ East, respectively. Cavendish banana fruits were harvested in mid-august 2016 while the Keitt mangoes were harvested in January 2017. The fruits collected were of uniform size, and at the green-yellowish maturity stage based on colour, firmness and total soluble solids (Brix). They were transported to the laboratory of "Technology and Food Analyses”, Agriculture Division, Instituto Superior Politécnico de Manica (ISPM).

\subsection{Centesimal Composition Determination}

The raw material (Keitt mango and Cavendish banana fruits) was characterised according to its centesimal composition in relation to water content (moisture), ash, crude lipids, crude proteins, fibre [23] and carbohydrates. Moisture content was determined in a vacuum oven at $105^{\circ} \mathrm{C}$. Protein content was analyzed by the Kjeldahl method using a conversion factor of 6.25. Lipid content was determined 
by the Soxhlet method based on petroleum ether (boiling point $52^{\circ} \mathrm{C}$ ) extraction. The ash content (fixed mineral residue) was measured gravimetrically after calcination of the samples in the muffle furnace (oven) at $550^{\circ} \mathrm{C}$. The fiber was determined by acid hydrolysis. The sugar fraction was determined by the difference between 100 and the total sum of all other constituents.

\subsection{Firmness Measurements}

The mango and banana fruits firmness measurement was determined using a food penetrometer $\left(0.2 \mathrm{~kg} / \mathrm{cm}^{2}\right.$ scale indicator, $10 \mathrm{~mm}$ indenter penetration depth and $3.5 \mathrm{~mm}$ probe size, ELCOMP (PTY) LTD Midrand, South Africa). The peel firmness (expressed in $\times 10^{5} \mathrm{~Pa}$ ) is defined as the mean of the pressure applied on the peel for one second to break the peel. Each fruit was compressed $3.5 \mathrm{~mm}$ at different locations of the skin around the fruit equator.

\subsection{Colour Measurements}

Skin colour of the fruit was measured using a colour differential meter (ZE-2000, Nippon Denshoku, Japan) to determine Hunter Lab's $L^{*}$ value (lightness or brightness), $\mathrm{a}^{\star}$ value (redness or greenness), and $\mathrm{b}^{\star}$ value (yellowness or blueness) of the fruit at the equator. The colorimeter was calibrated with a white standard tile.

\subsection{Brix Degree Measurement}

Total soluble solids were determined as ${ }^{\circ}$ Brix using a refractometer ATAGO hand held type (ELCOMP (PTY) LTD Midrand, South Africa), which was calibrated with distilled water and maintained at a constant temperature of $25^{\circ} \mathrm{C}$.

\subsection{Water Activity Measurement}

The water activity $\left(\mathrm{A}_{\mathrm{w}}\right)$ was determined at $25^{\circ} \mathrm{C}$ with the use of the Aqualab model CX-2T (Decagon Devices Inc., Pullman, WA, USA).

\section{7. pH Measurement}

The $\mathrm{pH}$ was measured by using a $\mathrm{pH}$ tester (APEX lab equipment, Hebi City, Qibin District, China), with an electrode for liquids previously calibrated with standard buffer solutions at different $\mathrm{pH}$ values $(\mathrm{pH}=4.0$ and $\mathrm{pH}=7.0)$. The mangoes or bananas were washed, peeled and liquefied using fruit pressing machine (ELCOMP (PTY) LTD Midrand, South Africa) to obtain juice. Fifty ml of mango or banana juice were taken and the $\mathrm{pH}$ was measured by direct immersion of the electrode in juice.

\subsection{Titratable Acidity Measurement}

Titratable acidity (TA), expressed as percentage of citric acid for mango and malic acid for banana, was determined by titrating with $0.1 \mathrm{~N} \mathrm{NaOH}$. The fruits were washed, peeled and liquefied to obtain the juice. Ten $\mathrm{ml}$ of the mango or 
banana juice were accurately measured and transferred into a conical flask. Into each of the flasks, 3 drops of phenolphthalein (1\%) were added as an indicator according to [23] official method 925.53 .

\subsection{Ascorbic Acid Determination}

An oxidation-reduction titration was performed according to the method established by Reference [24]. An iodine solution of known concentration was prepared and its concentration verified by titrating a solution of ascorbic acid. The iodine solution thus prepared was, then, used to titrate the respective fruit extracts. The ascorbic acid was expressed as g ascorbic acid per $1000 \mathrm{~mL}$ of fruit extract.

\subsection{Dip Treatment with Hot Water and Calcium Chloride}

The optimization of the postharvest treatments for the mango and bananas fruits experiments was conducted in two stainless steel equipment (pan). The temperature of the solutions was measured by a thermocouple. During the experiments, the stainless steel equipment was sealed in order to maintain the internal pressure. Arranged in a single layer, simulating the real situation of fruit handling the whole mango or banana samples were placed in small plastic perforated hammock, closed and then immersed in the solution and each having 3 replicate fruits. These plastic perforated hammocks allow the contact between fruit and solution and the identification of each sample, by their position inside them. All dip assays with the postharvest treatments were held for a total of 10 minutes (5 min in each treatment). Since the water temperature varies, the calcium chloride solution temperature was kept constant at $40^{\circ} \mathrm{C}$. The samples were removed from the solution and immediately immersed in a cold bath composed of ice and cold distilled water. The samples were allowed to cool in the ice water for 20 seconds. This procedure is commonly applied to stop the mass transfer and remove the solution from the food surface [25] [26] [27]. Due to the short contact between the food and the liquid, there is no significant rehydration. They were allowed to drain and thereafter held under ambient conditions. The fruits were carefully dried with paper towels to remove the bath water or solution. The samples were placed in hermetic containers and kept under refrigeration $\left(7^{\circ} \mathrm{C}\right)$ for further analysis within 48 hours after the procedure. The samples were analyzed for the centesimal composition, firmness, colour, ${ }^{\circ} \mathrm{Brix}, \mathrm{A}_{\mathrm{w}}, \mathrm{pH}$, titratable acidity and vitamin $\mathrm{C}$

\subsection{Central Composite Statistical Design}

Two sets of treatment were performed namely, hot water temperature and calcium chloride concentration. An experimental central composite design with twelve experiments according to a $2^{2}$ factorial design, with 4 axial points and 4 replicates at central point was employed. The experiments were conducted with

${ }^{1}$ For purposes of creating a logical argument, in this work, will be considered $45-65^{\circ} \mathrm{C}$ temperature range as hot water. 
Table 1. Matrix design with coded and decoded variables' values.

\begin{tabular}{ccccc}
\hline & \multicolumn{4}{c}{ variables } \\
\cline { 2 - 5 } Assay & \multicolumn{2}{c}{ Coded } & \multicolumn{2}{c}{ Decoded } \\
\cline { 2 - 5 } & Hot water $\left({ }^{\circ} \mathrm{C}\right)$ & Calcium chloride $(\%)$ & $X_{1}\left({ }^{\circ} \mathrm{C}\right)$ & $X_{2}(\%)$ \\
\hline 1 & -1 & -1 & 50 & 2 \\
3 & 1 & -1 & 60 & 2 \\
4 & -1 & 1 & 50 & 4 \\
5 & 1 & 1 & 60 & 4 \\
6 & -1.41 & 0 & 47.95 & 3 \\
7 & 1.41 & 0 & 62.05 & 3 \\
8 & 0 & -1.41 & 55 & 0.88 \\
9 & 0 & 1.41 & 55 & 5.12 \\
10 & 0 & 0 & 55 & 3 \\
11 & 0 & 0 & 55 & 3 \\
12 & 0 & 0 & 55 & 3 \\
\hline
\end{tabular}

hot water $\left(X_{1}\right)$ and calcium chloride $\left(X_{2}\right)$ separately for mango and banana fruits, according to the matrix design (Table 1 ).

By means of a regression analysis, each answer $(Y)$ statistically significant was adjusted to a second-order polynomial with the explanatory variables $\left(X_{n}\right)$. The general expression used to predict the behaviour of each response assessed is described as follows:

$$
Y_{i}=\beta_{0}+\beta_{1} X_{1}+\beta_{2} X_{2}+\beta_{11} X_{1}^{2}+\beta_{22} X_{2}^{2}+\beta_{12} X_{1} X_{2}+\varepsilon
$$

where $Y_{i}$ is the predicted response and $X_{1}$ and $X_{2}$ are the independent variables (hot water temperature and calcium chloride concentration, respectively); $\beta_{0}$ is the coefficient for the intercept of the plane with the axis response; $\beta_{1}$ and $\beta_{2}$ are the linear coefficients by the method of least squares; $\beta_{11}$ and $\beta_{22}$ are the variable quadratic coefficients; $\beta_{12}$ is the coefficients of interaction between independent variables; $\varepsilon$ is the experimental error.

The model was adjusted through the technique of 'backward elimination procedure' that allows one to examine the best regression, thus eliminating insignificant terms $\left(p<0.05\right.$ and $\left.R^{2} \geq 0.80\right)$. This includes the statistical significance of each terms of the adjustable model ( $p$-value), the estimated effects in each term $\left(\beta_{i}\right)$, the determination coefficient of the model $\left(R^{2}\right)$, in order to establish the accuracy of the model using the software Statistic 8.0 (StatSoft, Inc., Tulsa, OK, EUA) [28]. The three-dimensional response surface graphics, as well as their respective boundary curves, were also obtained.

\subsection{Optimization and Validation of the Process Conditions}

The resulting models were optimized to determine the levels of the variables that 
gave the optimum values of the responses and complete models were adopted for prediction of the optimum condition of hot water and calcium chloride treatment for the Keitt mango and Cavendish banana fruits. In this optimization, the multiple responses were also performed to develop an optimum for each experimental design, according to desirability or each dependent variable, combined into an overall composite function, called the desirability function.

For optimization, the predicted response that was not statistically affected with the independent variables $(p<0.05)$ was not considered. Simultaneous optimization of responses was carried out according to the methodology proposed by Reference [29]. The method is based on converting each response variable $\left(Y_{i}\right)$ in an individual desirability function $\left(d_{i}\right)$ with restricted range values $[0,1]$, where zero is assigned to an undesirable response and the 1 is assigned to a desirable response. Once the individual desirability functions for the predicted values of each variable response is specified, they are combined into a global desirability (D) through the geometric mean of $\mathrm{n}$ individual desirability (Equation (2)) which was maximized (D values close to 1 ) and reduces the simultaneous optimization to a single value.

$$
D=\left(d_{1} x d_{2} x d_{3} \cdots x d_{n}\right)^{\frac{1}{n}}
$$

Therefore, with the aid of the desirability function the set of optimized conditions of the process of combined hot water temperature dipping and calcium chloride concentration treatment to the selected physico-chemical parameters of the mango and banana fruits was obtained. This took into account the maximization of firmness, fiber and tritratable acidity, minimization moisture, water activity and $\mathrm{pH}$ as well as the maintenance of the colour, ash, lipids and vitamin C.

To achieve the validation of the predicted process conditions an experiment was conducted by using the conditions established by the optimization as well as comparing the values predicted by the models to experimentally obtained values.

\section{Results and Discussion}

\subsection{Effect of Hot Water and Calcium Chloride on the Centesimal Fruit Composition}

Based on the central composite design (CCD) carried out with two variables, the results on the Keitt mango and Cavendish banana fruits centesimal composition are presented in Table 2(a) while the effects of the variables are shown in Table 2(b). From the results on the Table 2(a), it is observed that for mango fruits, high values are obtained in assays 6 and 10 for moisture (85.74\%), 1 and 7 for ash $(0.18 \%), 8$ for lipids $(0.40 \%), 7$ for protein $(0.80 \%), 4$ for fiber $(3.75 \%)$ and 1 for carbohydrates. It is also observed that low values were obtained in assay 7 (82.38\%) for moisture, 5 and $8(0.11 \%)$ for ash, $5(0.16 \%)$ for lipids, $11(0.31 \%)$ for protein, $2(0.59 \%)$ for fiber and (10.01\%) for carbohydrates.

For banana fruits, it is observed that high values are obtained in assays 10 for moisture (82.59\%), 3 for ash and lipids (0.70\% and 3.02\%, respectively), 7 for 
Table 2. (a) Central composite design assay on the centesimal composition of Keitt mango and Cavendish banana fruits. (b) Effect of central composite design variables on the centesimal composition of Keitt mango and Cavendish banana fruits.

(a)

\begin{tabular}{|c|c|c|c|c|c|c|c|c|c|c|c|c|c|c|}
\hline \multirow{2}{*}{ Assay } & \multicolumn{2}{|c|}{ Variable } & \multicolumn{2}{|c|}{ Moisture (\%) } & \multicolumn{2}{|c|}{ Ash (\%) } & \multicolumn{2}{|c|}{ Lipid (\%) } & \multicolumn{2}{|c|}{ Protein (\%) } & \multicolumn{2}{|c|}{ Fiber (\%) } & \multicolumn{2}{|c|}{ Carbohyd (\%) } \\
\hline & $X_{1}$ & $X_{2}$ & $\mathrm{Ma}$ & $\mathrm{Ba}$ & $\mathrm{Ma}$ & $\mathrm{Ba}$ & $\mathrm{Ma}$ & $\mathrm{Ba}$ & $\mathrm{Ma}$ & $\mathrm{Ba}$ & $\mathrm{Ma}$ & $\mathrm{Ba}$ & $\mathrm{Ma}$ & $\mathrm{Ba}$ \\
\hline 1 & -1 & -1 & $80.78^{\mathrm{Ab}}$ & $76.57^{\mathrm{Ed}}$ & $0.18^{\mathrm{Aa}}$ & $0.58^{\mathrm{Ed}}$ & $0.29^{\mathrm{Ab}}$ & $2.37^{\mathrm{Dd}}$ & $0.55^{\mathrm{Aa}}$ & $2.74^{\mathrm{Dd}}$ & $2.57^{\mathrm{Aa}}$ & $2.57^{\mathrm{Dd}}$ & $15.64^{\mathrm{Aa}}$ & $15.16^{\mathrm{Dd}}$ \\
\hline 2 & 1 & -1 & $83.06^{\mathrm{Aa}}$ & $70.90^{\text {Dd }}$ & $0.15^{\mathrm{Aa}}$ & $0.68^{\mathrm{Ee}}$ & $0.23^{\mathrm{Aa}}$ & $2.68^{\mathrm{Dd}}$ & $0.44^{\mathrm{Aa}}$ & $2.21^{\mathrm{Dd}}$ & $0.59^{\mathrm{Aa}}$ & $0.59^{\mathrm{Dd}}$ & $15.49^{\mathrm{Aa}}$ & $22.94^{\mathrm{Dd}}$ \\
\hline 3 & -1 & 1 & $84.59^{\mathrm{Ab}}$ & $78.62^{\mathrm{Ee}}$ & $0.14^{\mathrm{Aa}}$ & $0.70^{\mathrm{Ee}}$ & $0.29^{\mathrm{Ab}}$ & $3.02^{\mathrm{Dd}}$ & $0.54^{\mathrm{Aa}}$ & $2.68^{\mathrm{Dd}}$ & $1.63^{\mathrm{Aa}}$ & $1.63^{\mathrm{Dd}}$ & $12.84^{\mathrm{Aa}}$ & $13.35^{\mathrm{Dd}}$ \\
\hline 4 & 1 & 1 & $84.86^{\mathrm{Ab}}$ & $73.27^{\text {Dd }}$ & $0.17^{\mathrm{Aa}}$ & $0.62^{\mathrm{Ee}}$ & $0.36^{\mathrm{Ac}}$ & $0.79^{\mathrm{Dd}}$ & $0.72^{\mathrm{Aa}}$ & $3.61^{\mathrm{Dd}}$ & $3.75^{\mathrm{Aa}}$ & $3.75^{\mathrm{Dd}}$ & $10.15^{\mathrm{Aa}}$ & $17.96^{\mathrm{Dd}}$ \\
\hline 5 & -1.41 & 0 & $85.18^{\mathrm{Ab}}$ & $74.25^{\mathrm{Ed}}$ & $0.11^{\mathrm{Aa}}$ & $0.52^{\mathrm{Dd}}$ & $0.16^{\mathrm{Aa}}$ & $2.01^{\mathrm{Dd}}$ & $0.52^{\mathrm{Aa}}$ & $2.62^{\mathrm{Dd}}$ & $2.78^{\mathrm{Aa}}$ & $2.78^{\mathrm{Dd}}$ & $11.19^{\mathrm{Aa}}$ & $17.81^{\mathrm{Dd}}$ \\
\hline 6 & 1.41 & 0 & $85.74^{\mathrm{Ab}}$ & $73.76^{\mathrm{Dd}}$ & $0.17^{\mathrm{Aa}}$ & $0.54^{\mathrm{Dd}}$ & $0.36^{\mathrm{Ab}}$ & $2.26^{\mathrm{Dd}}$ & $0.65^{\mathrm{Aa}}$ & $3.26^{\mathrm{Dd}}$ & $3.07^{\mathrm{Aa}}$ & $3.07^{\mathrm{Dd}}$ & $10.01^{\mathrm{Aa}}$ & $17.10^{\mathrm{Dd}}$ \\
\hline 7 & 0 & -1.41 & $82.38^{\mathrm{Aa}}$ & $73.97^{\mathrm{Dd}}$ & $0.18^{\mathrm{Aa}}$ & $0.69^{\mathrm{Ee}}$ & $0.25^{\mathrm{Ab}}$ & $2.27^{\mathrm{Dd}}$ & $0.80^{\mathrm{Aa}}$ & $4.02^{\mathrm{Dd}}$ & $3.10^{\mathrm{Aa}}$ & $3.10^{\mathrm{Dd}}$ & $13.30^{\mathrm{Aa}}$ & $15.95^{\mathrm{Dd}}$ \\
\hline 8 & 0 & 1.41 & $83.28^{\mathrm{Aa}}$ & $75.19^{\mathrm{Ed}}$ & $0.11^{\mathrm{Aa}}$ & $0.70^{\mathrm{Ee}}$ & $0.40^{\mathrm{Ac}}$ & $1.94^{\mathrm{Dd}}$ & $0.47^{\mathrm{Aa}}$ & $2.33^{\mathrm{Dd}}$ & $1.71^{\mathrm{Aa}}$ & $1.71^{\mathrm{Dd}}$ & $14.15^{\mathrm{Aa}}$ & $18.12^{\mathrm{Dd}}$ \\
\hline 9 & 0 & 0 & $84.25^{\mathrm{Ab}}$ & $77.00^{\mathrm{Ed}}$ & $0.16^{\mathrm{Aa}}$ & $0.62^{\mathrm{Ee}}$ & $0.31^{\mathrm{Ac}}$ & $1.95^{\mathrm{Dd}}$ & $0.52^{\mathrm{Aa}}$ & $2.62^{\mathrm{Dd}}$ & $1.89^{\mathrm{Aa}}$ & $1.89^{\mathrm{Dd}}$ & $13.02^{\mathrm{Aa}}$ & $15.92^{\mathrm{Dd}}$ \\
\hline 10 & 0 & 0 & $85.74^{\mathrm{Ab}}$ & $82.59^{\mathrm{Fe}}$ & $0.17^{\mathrm{Aa}}$ & $0.63^{\mathrm{Ee}}$ & $0.23^{\mathrm{Aa}}$ & $1.93^{\mathrm{Dd}}$ & $0.65^{\mathrm{Aa}}$ & $3.26^{\mathrm{Dd}}$ & $1.71^{\mathrm{Aa}}$ & $1.71^{\mathrm{Dd}}$ & $11.66^{\mathrm{Aa}}$ & $9.88^{\mathrm{Dd}}$ \\
\hline 11 & 0 & 0 & $85.58^{\mathrm{Ab}}$ & $82.18^{\mathrm{Fe}}$ & $0.16^{\mathrm{Aa}}$ & $0.63^{\mathrm{Ee}}$ & $0.29^{\mathrm{Ab}}$ & $1.93^{\mathrm{Dd}}$ & $0.31^{\mathrm{Aa}}$ & $1.57^{\mathrm{Dd}}$ & $1.91^{\mathrm{Aa}}$ & $1.91^{\mathrm{Dd}}$ & $11.91^{\mathrm{Aa}}$ & $11.78^{\mathrm{Dd}}$ \\
\hline 12 & 0 & 0 & $84.25^{\mathrm{Ab}}$ & $78.65^{\mathrm{Fe}}$ & $0.16^{\mathrm{Aa}}$ & $0.64^{\mathrm{Ee}}$ & $0.27^{\mathrm{Ab}}$ & $1.96^{\mathrm{Dd}}$ & $0.58^{\mathrm{Aa}}$ & $2.91^{\mathrm{Dd}}$ & $1.91^{\mathrm{Aa}}$ & $1.91^{\mathrm{Dd}}$ & $12.99^{\mathrm{Aa}}$ & $13.93^{\mathrm{Dd}}$ \\
\hline
\end{tabular}

$X_{1}$ and $X_{2}$ correspond to the independent variable. $X_{1}$ is the hot water temperature $\left({ }^{\circ} \mathrm{C}\right) ; X_{2}$ is the calcium chloride concentration (\%); Ma-mango fruits; $\mathrm{Ba}-$ Banana fruits. Each column, means followed by the same script capital letter is not significantly different $(p<0.05)$ by Tukey test between hot water temperature and, the same lower case is not significantly different between calcium chloride concentration. Were used $a, b$ and $c$ for mango and $d, e$ and $f$ for banana fruits.

(b)

\begin{tabular}{cccccccccccccc}
\hline Variable & \multicolumn{2}{c}{ Moisture } & \multicolumn{2}{c}{ Ash } & \multicolumn{2}{c}{ Lipids } & \multicolumn{2}{c}{ Protein } & \multicolumn{3}{c}{ Fiber } & \multicolumn{2}{c}{ Carbohy } \\
\hline Fruit & Ma & Ba & Ma & Ba & Ma & Ba & Ma & Ba & Ma & Ba & Ma & Ba \\
\hline$R^{2}$ & 0.76 & 0.74 & 0.62 & 0.93 & 0.71 & 0.76 & 0.26 & 0.26 & 0.66 & 0.66 & 0.56 & 0.57 \\
Average & 84.96 & 80.10 & 0.16 & 0.63 & 0.27 & 1.94 & 0.52 & 2.59 & 1.86 & 1.86 & 12.39 & 12.88 \\
$X_{1}$ & 0.84 & -2.94 & 0.02 & 0.01 & 0.07 & -0.39 & 0.07 & 0.33 & 0.14 & 0.14 & -1.13 & 2.86 \\
$X_{1}^{2}$ & 0.09 & $-5.84^{*}$ & -0.02 & $-0.08^{*}$ & -0.01 & 0.24 & 0.05 & 0.22 & 0.81 & 0.81 & -1.11 & 4.65 \\
$X_{2}$ & 1.72 & 1.54 & -0.03 & 0.02 & $0.09^{*}$ & -0.43 & -0.05 & -0.26 & 0.06 & 0.06 & -1.74 & -0.93 \\
$X_{2}^{2}$ & $-2.55^{*}$ & $-5.26^{*}$ & -0.01 & $0.08^{*}$ & 0.05 & 0.21 & 0.09 & 0.46 & 0.28 & 0.28 & 2.03 & 4.22 \\
$X_{1} X_{2}$ & -1.01 & 0.16 & 0.03 & $-0.09^{*}$ & 0.07 & $-1.27^{*}$ & 0.15 & 0.73 & $2.03^{*}$ & $2.05^{*}$ & -1.27 & -1.58 \\
\hline
\end{tabular}

${ }^{*}$ Significant effects at $95 \%$ confidence level. $X_{1}$ and $X_{2}$ correspond to the independent variable. $X_{1}$ is the hot water temperature $\left({ }^{\circ} \mathrm{C}\right) ; X_{2}$ is the calcium chloride concentration (\%); $X_{1}^{2}$ and $X_{2}^{2}$ are the variable quadratic coefficients; $X_{1} X_{2}$ is the coefficients of interaction between independent variables and $R^{2}$ is the determination coefficient. Ma-mango fruits; Ba-Banana fruits.

proteins $(4.02 \%), 4$ for fiber (3.75\%) and 2 for carbohydrates (22.94\%). It is also observed that low values were obtained in assay 2 for moisture and fiber $(70.90 \%$ and $0.59 \%$ respectively), 5 for ash $(0.52 \%), 4$ for lipids $(0.79 \%), 11$ for proteins (1.57\%) and 10 for carbohydrates (9.88\%). Other reports suggest that combining hot water and calcium chloride prevents the destruction of cell compartments and also the contact of PolyPhenolOxidase with polyphenols in the vacuole [30] 
without degrading the centesimal attributes. This observation may be due to the optimization of specified set of parameter in the current study. When optimizing a process, the goal is to maximize one or more of the process specifications, while keeping all others within their constraints [28].

It can be observed, in Table 2(b) that, hot water temperature dipping was not statistically influent on centesimal mango fruits composition but the linear term of calcium chloride was influent on the lipids and the quadratic terms of calcium chloride concentration was statistically influent on the moisture content with confidence level of $95 \%$. The interaction between hot water dipping and calcium chloride treatment was statistically significant $(p<0.05)$ for fibers content.

For banana fruits, it can be observed, in Table 2(b) that, quadratic terms of calcium chloride concentration and hot water temperature was statistically influent on the moisture and ash content with confidence level of 95\%. The interaction between hot water dipping and calcium chloride treatment was statistically significant $(p<0.05)$ for ash, lipids and fibers content.

Reports on hot water and calcium chloride on the Keitt mango and Cavendish banana fruits centesimal composition are scarce. Maureen et al., (2016) studying the effects of induced ripening on the proximate, biochemical and mineral compositions of Musa sapientum (Banana) reported that there are significant differences in the percentage of proximate composition. In this report, the moisture content, dry matter, ash, crude fibre, ether extract, crude protein and carbohydrate of the plantain were compared. The hot water dipping was reported as the method that did not induce ripening as the respective values were lowest. Similar results were reported by [31] on the proximate, biochemical and mineral compositions of Carica papaya (Pawpaw Fruit). Rerefence [32] was comparing proximate analysis, mineral elements and anti-nutrients composition between Musa sapientum (Banana) and Musa paradisiaca (Plantain) pulp flour and reported that no significant difference was observed when the moisture, ash, crude fibre, crude fat, crude protein and total carbohydrate contents of the two Musa species were compared to each other at $p<0.05$.

\subsection{Effect of Hot Water and Calcium Chloride on the Firmness and Colour Attributes}

The central composite design (CCD) matrix with the codified variables and the results on the firmness and colour attributes of Keitt mango and Cavendish banana fruits are presented in Table 3(a) and the effect of the variables, in Table 3(b).

It can be seen, in Table 3(a), that assay 5, where the high hot water temperature and calcium chloride were used, presented higher firmness value $(12.00 \times$ $10^{5} \mathrm{~Pa}$ ) and the assay 6 , where highest hot water temperature was used and medium calcium chloride concentration obtained the lower value $\left(3.67 \times 10^{5} \mathrm{~Pa}\right)$. It can be observed, in Table $3(\mathrm{~b})$, that the interaction between hot water dipping and calcium chloride treatment statistically $(p<0.05)$ influenced the mango fruits peel firmness with confidence level of $95 \%$. 
For banana fruits, in Table 3(a), it is seen that assay 5, where the lowest hot water temperature was used and medium calcium chloride value, presented higher firmness value $\left(10.00 \times 10^{5} \mathrm{~Pa}\right)$ and the assay 8 , where medium hot water temperature was used and high calcium chloride concentration obtained the lower value $\left(7.33 \times 10^{5} \mathrm{~Pa}\right)$. It can be observed, in Table $3(\mathrm{~b})$, that with exception of calcium chloride concentration, hot water temperature significantly $(p<$ $0.05)$ influenced the banana fruits peel firmness.

Reference [33] reported opposite behaviour when were assessing the effectiveness of calcium chloride and calcium lactate on maintenance of textural and sensory qualities of fresh-cut mangoes where they noted that fresh-cut mango firmness was increasing when the calcium content used increased. In this work with mango and banana fruits, the high codified variable values reduced the mango and banana fruits peel firmness. Similar fruit peel firmness behaviour was reported by the reference [19]. These researchers assessed the effect of hot water and reported the submergence time and storage duration on quality of dragon fruit (Hylocereus polyrhizus). They observed that increasing of hot water temperature decreased the dragon fruit firmness significantly. Therefore, disturbance in cell structure and membrane damaged on fruit which was soaked in high water temperature was the source of decrease in fruit firmness.

The cell walls are more stable to different treatments, therefore, calcium dips have been employed to improve firmness and extend the postharvest shelf life of a wide range of fruits and vegetables. References [34] and [35] reported that calcium salts are better in the strengthening of cell walls. The current results are also similar with those reported by the reference [36] on pomegranate. They associated the retention of firmness in calcium ions treated fruits to their accumulation in the cell walls leading to facilitation in the cross linking of the pectic polymers. The cross linking increases wall strength and cell cohesion.

With respect to Keitt mango fruits colour attributes, the hot water temperature and calcium chloride concentration acted in order to obtain high values in assay 9,3 and 1 (44.32, 1.46 and 21.32) and low values in assay 5, 5 and 2 (42.23, -7.94 and 17.53), respectively for $\mathrm{L}, \mathrm{a}^{*}$ and $\mathrm{b}^{*}$ attributes. Moreover, it was observed from the difference between the highest and lowest values obtained $(\mathrm{L}=$ 2.09 and $\left.\mathrm{a}^{*}=6.48\right)$ that the treatments did not cause high change on the mango fruits peel colour. From the Table 3(b), the hot water temperature and calcium chloride concentration were statistically influential in the quadratic term of hot water temperature on $\mathrm{L}$ values (lighteness intensity), linear term hot water and quadratic term of calcium chloride on $b^{\star}$ (yellowness or blueness). The interaction between hot water dipping and calcium chloride treatment was statistically significant $(p<0.05)$ for $\mathrm{a}^{*}$ and $\mathrm{b}^{*}$ colour attributes.

Banana fruits colour attributes showed that, the hot water temperature and calcium chloride concentration acted in order to obtain high values in assay 10 , 2 and $1(44.80,-32.51$ and 41.60) and low values in assay 3, 8 and $2(42.88$, -37.29 and 37.01), respectively for $\mathrm{L}, \mathrm{a}^{\star}$ and $\mathrm{b}^{\star}$ attributes. Moreover, it was 
Table 3. (a) Central composite design assay on the firmness and colour attributes of Keitt mango and Cavendish banana fruits; (b) Effect of central composite design variables on the firmness and colour attributes of Keitt mango and Cavendish banana fruits.

(a)

\begin{tabular}{|c|c|c|c|c|c|c|c|c|c|c|}
\hline \multirow[b]{3}{*}{ Essay } & \multirow{2}{*}{\multicolumn{2}{|c|}{ Variable }} & \multicolumn{8}{|c|}{ Fruit and physico-chemical parameters } \\
\hline & & & \multicolumn{2}{|c|}{ Firmness $\left(\times 10^{5} \mathrm{~Pa}\right)$} & \multicolumn{2}{|c|}{$\mathrm{L}$} & \multicolumn{2}{|c|}{$a^{*}$} & \multicolumn{2}{|c|}{$b^{*}$} \\
\hline & $X_{1}\left({ }^{\circ} \mathrm{C}\right)$ & $X_{2}(\%)$ & Mango & Banana & Mango & Banana & Mango & Banana & Mango & Banana \\
\hline 1 & -1 & -1 & $10.00^{\mathrm{Aa}}$ & $8.67^{\mathrm{Dd}}$ & $42.88^{\mathrm{Ba}}$ & $44.66^{\mathrm{Dd}}$ & $-5.87^{\mathrm{Aa}}$ & $-37.25^{\mathrm{Dd}}$ & $21.32^{\mathrm{Bb}}$ & $41.60^{\mathrm{Dd}}$ \\
\hline 2 & 1 & -1 & $4.20^{\mathrm{Aa}}$ & $7.67^{\mathrm{Dd}}$ & $43.00^{\mathrm{Ba}}$ & $44.77^{\mathrm{Dd}}$ & $-2.51^{\mathrm{Aa}}$ & $-32.51^{\mathrm{Ee}}$ & $17.53^{\mathrm{Aa}}$ & $37.01^{\mathrm{Dd}}$ \\
\hline 3 & -1 & 1 & $4.33^{\mathrm{Aa}}$ & $8.67^{\mathrm{Dd}}$ & $42.88^{\mathrm{Ba}}$ & $42.88^{\text {Dd }}$ & $1.46^{\mathrm{Aa}}$ & $-36.66^{\mathrm{De}}$ & $19.13^{\mathrm{Bb}}$ & $40.97^{\mathrm{Ed}}$ \\
\hline 4 & 1 & 1 & $12.00^{\mathrm{Aa}}$ & $7.33^{\mathrm{Dd}}$ & $42.88^{\mathrm{Ba}}$ & $43.19^{\mathrm{Dd}}$ & $-7.46^{\mathrm{Aa}}$ & $-35.78^{\mathrm{Ee}}$ & $19.96^{\mathrm{Bb}}$ & $39.39^{\mathrm{Dd}}$ \\
\hline 5 & -1.41 & 0 & $11.70^{\mathrm{Aa}}$ & $10.00^{\mathrm{Ed}}$ & $42.23^{\mathrm{Aa}}$ & $43.51^{\mathrm{Dd}}$ & $-7.94^{\mathrm{Aa}}$ & $-36.87^{\mathrm{De}}$ & $20.54^{\mathrm{Bb}}$ & $40.63^{\mathrm{Ed}}$ \\
\hline 6 & 1.41 & 0 & $3.67^{\mathrm{Aa}}$ & $7.67^{\mathrm{Dd}}$ & $42.33^{\mathrm{Aa}}$ & $43.82^{\text {Dd }}$ & $-4.89^{\mathrm{Aa}}$ & $-35.79^{\mathrm{Ee}}$ & $18.77^{\mathrm{Ab}}$ & $39.24^{\mathrm{Dd}}$ \\
\hline 7 & 0 & -1.41 & $11.00^{\mathrm{Aa}}$ & $8.00^{\mathrm{Dd}}$ & $42.77^{\mathrm{Ba}}$ & $43.22^{\mathrm{Dd}}$ & $0.06^{\mathrm{Aa}}$ & $-35.02^{\mathrm{Ee}}$ & $18.15^{\mathrm{Ab}}$ & $39.72^{\mathrm{Dd}}$ \\
\hline 8 & 0 & 1.41 & $7.33^{\mathrm{Aa}}$ & $7.33^{\mathrm{Dd}}$ & $42.66^{\mathrm{Ba}}$ & $43.82^{\mathrm{Dd}}$ & $-2.66^{\mathrm{Aa}}$ & $-37.29^{\mathrm{Dd}}$ & $19.11^{\mathrm{Bb}}$ & $40.75^{\mathrm{Ed}}$ \\
\hline 9 & 0 & 0 & $11.00^{\mathrm{Aa}}$ & $7.67^{\mathrm{Dd}}$ & $44.32^{\mathrm{Ba}}$ & $43.53^{\mathrm{Dd}}$ & $-1.00^{\mathrm{Aa}}$ & $-35.44^{\mathrm{Ee}}$ & $20.85^{\mathrm{Bb}}$ & $39.84^{\mathrm{Dd}}$ \\
\hline 10 & 0 & 0 & $12.00^{\mathrm{Aa}}$ & $7.67^{\mathrm{Dd}}$ & $43.92^{\mathrm{Ba}}$ & $44.80^{\mathrm{Dd}}$ & $-5.03^{\mathrm{Aa}}$ & $-35.47^{\mathrm{Ee}}$ & $18.93^{\mathrm{Bb}}$ & $39.99^{\mathrm{Dd}}$ \\
\hline 11 & 0 & 0 & $11.70^{\mathrm{Aa}}$ & $8.00^{\mathrm{Dd}}$ & $42.77^{\mathrm{Ba}}$ & $43.22^{\mathrm{Dd}}$ & $-2.42^{\mathrm{Aa}}$ & $-36.52^{\mathrm{De}}$ & $20.18^{\mathrm{Bb}}$ & $41.23^{\mathrm{Ed}}$ \\
\hline 12 & 0 & 0 & $11.00^{\mathrm{Aa}}$ & $7.67^{\mathrm{Dd}}$ & $43.31^{\mathrm{Ba}}$ & $43.82^{\mathrm{Dd}}$ & $0.72^{\mathrm{Aa}}$ & $-35.79^{\mathrm{Ee}}$ & $20.30^{\mathrm{Bb}}$ & $39.24^{\mathrm{Dd}}$ \\
\hline
\end{tabular}

$X_{1}$ and $X_{2}$ correspond to the independent variable. $X_{1}$ is the hot water temperature $\left({ }^{\circ} \mathrm{C}\right) ; X_{2}$ is the calcium chloride concentration $(\%)$; $\mathrm{a}^{*}$ and $\mathrm{b}^{\star}$ are the colour attributes. Each column, means followed by the same script capital letter is not significantly different $(p<0.05)$ between hot water temperature and, the same lower case between calcium chloride concentration by Tukey test. Were used $a, b$ and $c$ for mango and $d$, $e$ and $f$ for banana fruits.

(b)

\begin{tabular}{|c|c|c|c|c|c|c|c|c|}
\hline \multirow{2}{*}{ Variable } & \multicolumn{2}{|c|}{ Firmness } & \multicolumn{2}{|c|}{$\mathrm{L}^{*}$} & \multicolumn{2}{|c|}{$a^{*}$} & \multicolumn{2}{|c|}{$b^{*}$} \\
\hline & Mango & Banana & Mango & Banana & Mango & Banana & Mango & Banana \\
\hline$R^{2}$ & 0.75 & 0.95 & 0.56 & 0.20 & 0.68 & 0.79 & 0.83 & 0.73 \\
\hline Average & 11.43 & 7.75 & 43.58 & 43.84 & -1.93 & -35.81 & 20.07 & 40.08 \\
\hline$X_{1}$ & -2.37 & $-1.41^{\star}$ & 0.06 & 0.21 & -0.32 & $1.79^{\star}$ & $-1.37^{\star}$ & $-2.04^{\star}$ \\
\hline$X_{1}^{2}$ & -4.16 & $1.00^{*}$ & $-1.10^{*}$ & -0.03 & -4.37 & -0.18 & -0.24 & -0.32 \\
\hline$X_{2}$ & -0.76 & -0.32 & -0.07 & -0.63 & -0.37 & $-1.48^{\star}$ & 0.40 & 0.81 \\
\hline$X_{2}^{2}$ & -2.66 & -0.17 & -0.66 & -0.18 & 0.78 & 0.00 & $-1.27^{\star}$ & -0.01 \\
\hline$X_{1} X_{2}$ & $6.73^{\star}$ & -0.17 & -0.06 & 0.10 & $-6.14^{*}$ & -1.93 & $2.31^{*}$ & 1.50 \\
\hline
\end{tabular}

${ }^{*}$ Significant effects to $95 \%$ confidence level. $X_{1}$ and $X_{2}$ correspond to the independent variable. $X_{1}$ is the hot water temperature ( ${ }^{\circ} \mathrm{C}$ ); $X_{2}$ is the calcium chloride concentration (\%); $X_{1}^{2}$ and $X_{2}^{2}$ are the variable quadratic coefficients; $X_{1} X_{2}$ is the coefficients of interaction between independent variables and $R^{2}$ is the determination coefficient; $\mathrm{L}, \mathrm{a}^{*}$ and $\mathrm{b}^{*}$ are the colour attributes.

observed from the difference between the highest and lowest values obtained ( $\mathrm{L}$ $=1.92, \mathrm{a}^{*}=4.78$ and $\left.\mathrm{b}^{*}=4.59\right)$ that the treatments did not cause high change on the banana fruits peel colour. From the Table 3(b), the hot water temperature and calcium chloride concentration were statistically influential only in linear term of each one for $\mathrm{a}^{*}$ values (redness or greenness) and linear term of hot wa- 
ter temperature for $\mathrm{b}^{\star}$ (yellowness or blueness), but were not statistically significant for $\mathrm{L}$ (lightness or brightness) values.

It is desirable that the treatment carries to the smaller colour changes. Similar observations were reported by the reference [33] for Atkins and Kent mangoes when they applied calcium chloride. In a heat treatment, the colour variation is a very complex aspect. It is related to the moisture content, solids incorporated and pigment concentration. This is attributed to the hot water treatment which protect the ultra-structure of the pericarp cells in the heat-pretreated fruits and calcium treatment which decrease the incidence of physiological disorders. Greater variation on colour is obtained with the higher temperature and high concentrations of calcium chloride [27]. However, the hot water temperature and calcium chloride solution concentrations used in the present work were significantly lower than those reported by the reference [27].

\subsection{Effect of Hot Water and Calcium Chloride on the ${ }^{\circ} \mathrm{Brix}, \mathrm{Aw}, \mathrm{pH}$, TA and Vitamin C}

The ${ }^{\circ}$ Brix, $\mathrm{A}_{\mathrm{w}}, \mathrm{pH}, \mathrm{TA}$ and vitamin $\mathrm{C}$ values for Keitt mango and Cavendish banana fruits obtained after hot water and calcium chloride treatment are presented in Table 4(a) while the effect of central composite design variables are presented in Table 4(b). It can be observed, in Table 4(a), that low Keitt mangoes values were obtained in assays 10 for ${ }^{\circ} \mathrm{Brix}(11.33 \%), 8$ and 9 for $\mathrm{A}_{\mathrm{w}}$ (0.96), 11 and 12 for $\mathrm{pH}$ (4.01), 6 and 7 for TA (0.06\%) and 9 for vitamin $\mathrm{C}$ (9.13\%). High values were obtained in assay 1 for ${ }^{\circ}$ Brix (16.00\%), 2, 3, 5, 7 and 10 for $\mathrm{A}_{\mathrm{w}}(0.98), 4$ for $\mathrm{pH}(5.02), 1,3,5$ and 8 for TA $(0.10 \%)$ and 8 for vitamin C (14.83\%).

These results indicated that the hot water $\left(X_{1}\right)$ and calcium chloride $\left(X_{2}\right)$ were the most influential variables over the two responses studied. Therefore, in the present study, mangoes total soluble solids, water activity and vitamin $\mathrm{C}$ were not statistically affected $(p<0.05)$ by hot water dipping and calcium chloride treatment (Table 4(b)). Quadratic effect related to $X_{1}$ showed that the higher the temperature of hot water, the higher is the $\mathrm{pH}$. In a similar way, quadratic effect related to $X_{2}$ showed that the higher the calcium chloride treatment, the higher is the $\mathrm{pH}$. Linear effect related to $X_{1}$ showed that the higher the temperature of hot water, the smaller is the titratable acidity.

It can be observed, also, in Table 4(a), that low Cavendish bananas values were obtained in assays 2 for ${ }^{\circ} \mathrm{Brix}(11.30 \%), 1$ and 8 for $\mathrm{A}_{\mathrm{w}}$ (0.87), 10 for $\mathrm{pH}$ (4.51), 5 for TA $(0.11 \%)$ and 4 for vitamin C (1.20\%). High values were obtained in assay 3 for ${ }^{\circ}$ Brix (21.00), 3 and 6 for $\mathrm{A}_{\mathrm{w}}$ (0.94), 2 for $\mathrm{pH}$ (5.88), 2, 3, 11 and 12 for TA $(0.18 \%)$ and 2 for vitamin C (2.07\%).

In the present study, bananas total soluble solids, water activity and $\mathrm{pH}$ were not statistically affected $(p<0.05)$ by hot water dipping and calcium chloride treatment (Table 4(b)). Quadratic effect related to $X_{1}$ showed that the higher the temperature of hot water, the smaller is the titratable acidity. In the present 
Table 4. (a) Central composite design assay on the ${ }^{\circ} \mathrm{Brix}, \mathrm{A}_{\mathrm{w}}, \mathrm{pH}$, TA and vitamin $\mathrm{C}$ of Keitt mango and Cavendish banana fruits; (b) Effect of central composite design variables on the ${ }^{\circ} \mathrm{Brix}, \mathrm{A}_{\mathrm{w}}$, TA and vitamin $\mathrm{C}$ of Cavendish banana fruits.

(a)

\begin{tabular}{|c|c|c|c|c|c|c|c|c|c|c|c|c|}
\hline \multirow{2}{*}{ Assay } & \multicolumn{2}{|c|}{ Variable } & \multicolumn{2}{|c|}{ TSS } & \multicolumn{2}{|c|}{ Aw } & \multicolumn{2}{|c|}{$\mathrm{pH}$} & \multicolumn{2}{|c|}{ TA } & \multicolumn{2}{|c|}{ Vit. C } \\
\hline & $X_{1}\left({ }^{\circ} \mathrm{C}\right)$ & $X_{2}(\%)$ & $\mathrm{Ma}$ & $\mathrm{Ba}$ & $\mathrm{Ma}$ & $\mathrm{Ba}$ & $\mathrm{Ma}$ & $\mathrm{Ba}$ & $\mathrm{Ma}$ & $\mathrm{Ba}$ & $\mathrm{Ma}$ & $\mathrm{Ba}$ \\
\hline 1 & -1 & -1 & $16.00^{\mathrm{Aa}}$ & $12.00^{\mathrm{Ed}}$ & $0.97^{\mathrm{Aa}}$ & $0.87^{\mathrm{Dd}}$ & $4.94^{\mathrm{Ba}}$ & $5.36^{\mathrm{Dd}}$ & $0.10^{\mathrm{Ba}}$ & $0.17^{\mathrm{Ed}}$ & $12.87^{\mathrm{Aa}}$ & $1.77^{\mathrm{Dd}}$ \\
\hline 2 & 1 & -1 & $14.17^{\mathrm{Aa}}$ & $11.30^{\mathrm{Dd}}$ & $0.98^{\mathrm{Aa}}$ & $0.88^{\mathrm{Dd}}$ & $4.99^{\mathrm{Ba}}$ & $5.88^{\mathrm{Dd}}$ & $0.08^{\mathrm{ABa}}$ & $0.18^{\mathrm{Ed}}$ & $12.00^{\mathrm{Aa}}$ & $2.07^{\mathrm{Ed}}$ \\
\hline 3 & -1 & 1 & $13.50^{\mathrm{Aa}}$ & $21.00^{\mathrm{Ef}}$ & $0.98^{\mathrm{Aa}}$ & $0.94^{\mathrm{Dd}}$ & $5.00^{\mathrm{Bb}}$ & $5.85^{\mathrm{Dd}}$ & $0.10^{\mathrm{Ba}}$ & $0.18^{\mathrm{Ed}}$ & $10.10^{\mathrm{Aa}}$ & $2.03^{\mathrm{Ed}}$ \\
\hline 4 & 1 & 1 & $14.33^{\mathrm{Aa}}$ & $19.00^{\mathrm{Ef}}$ & $0.97^{\mathrm{Aa}}$ & $0.90^{\mathrm{Dd}}$ & $5.02^{\mathrm{Bb}}$ & $5.19^{\mathrm{Dd}}$ & $0.07^{\mathrm{Aa}}$ & $0.12^{\mathrm{Dd}}$ & $10.90^{\mathrm{Aa}}$ & $1.20^{\mathrm{Dd}}$ \\
\hline 5 & -1.41 & 0 & $14.33^{\mathrm{Aa}}$ & $13.30^{\mathrm{De}}$ & $0.98^{\mathrm{Aa}}$ & $0.89^{\mathrm{Dd}}$ & $4.97^{\mathrm{Ba}}$ & $5.02^{\mathrm{Dd}}$ & $0.10^{\mathrm{Ba}}$ & $0.11^{\mathrm{Dd}}$ & $12.70^{\mathrm{Aa}}$ & $1.40^{\mathrm{Dd}}$ \\
\hline 6 & 1.41 & 0 & $15.33^{\mathrm{Aa}}$ & $17.67^{\mathrm{Ee}}$ & $0.97^{\mathrm{Aa}}$ & $0.94^{\mathrm{Dd}}$ & $5.00^{\mathrm{Bb}}$ & $5.63^{\mathrm{Dd}}$ & $0.06^{\mathrm{Aa}}$ & $0.14^{\mathrm{Dd}}$ & $12.37^{\mathrm{Aa}}$ & $1.47^{\mathrm{Dd}}$ \\
\hline 7 & 0 & -1.41 & $15.33^{\mathrm{Aa}}$ & $19.33^{\mathrm{Ef}}$ & $0.98^{\mathrm{Aa}}$ & $0.89^{\mathrm{Dd}}$ & $5.00^{\mathrm{Bb}}$ & $5.38^{\mathrm{Dd}}$ & $0.06^{\mathrm{Aa}}$ & $0.16^{\mathrm{Ed}}$ & $12.63^{\mathrm{Aa}}$ & $1.93^{\mathrm{Ed}}$ \\
\hline 8 & 0 & 1.41 & $13.67^{\mathrm{Aa}}$ & $13.10^{\mathrm{Ed}}$ & $0.96^{\mathrm{Aa}}$ & $0.87^{\mathrm{Dd}}$ & $4.00^{\mathrm{Aa}}$ & $5.21^{\mathrm{Dd}}$ & $0.10^{\mathrm{Ba}}$ & $0.17^{\mathrm{Ed}}$ & $14.83^{\mathrm{Aa}}$ & $1.93^{\mathrm{Ed}}$ \\
\hline 9 & 0 & 0 & $13.67^{\mathrm{Aa}}$ & $16.33^{\mathrm{Ee}}$ & $0.96^{\mathrm{Aa}}$ & $0.92^{\mathrm{Dd}}$ & $4.15^{\mathrm{Aa}}$ & $5.45^{\mathrm{Dd}}$ & $0.07^{\mathrm{Aa}}$ & $0.16^{\mathrm{Ed}}$ & $9.13^{\mathrm{Aa}}$ & $1.80^{\mathrm{Dd}}$ \\
\hline 10 & 0 & 0 & $11.33^{\mathrm{Aa}}$ & $16.67^{\mathrm{Ee}}$ & $0.98^{\mathrm{Aa}}$ & $0.92^{\mathrm{Dd}}$ & $4.03^{\mathrm{Aa}}$ & $4.51^{\mathrm{Dd}}$ & $0.07^{\mathrm{Aa}}$ & $0.17^{\mathrm{Ed}}$ & $11.60^{\mathrm{Aa}}$ & $1.73^{\mathrm{Dd}}$ \\
\hline 11 & 0 & 0 & $15.50^{\mathrm{Aa}}$ & $16.00^{\mathrm{Ee}}$ & $0.97^{\mathrm{Aa}}$ & $0.92^{\mathrm{Dd}}$ & $4.01^{\mathrm{Aa}}$ & $4.70^{\mathrm{Dd}}$ & $0.07^{\mathrm{Aa}}$ & $0.18^{\mathrm{Ed}}$ & $12.87^{\mathrm{Aa}}$ & $1.70^{\mathrm{Dd}}$ \\
\hline 12 & 0 & 0 & $15.17^{\mathrm{Aa}}$ & $17.00^{\mathrm{Ee}}$ & $0.97^{\mathrm{Aa}}$ & $0.93^{\mathrm{Dd}}$ & $4.01^{\mathrm{Aa}}$ & $4.70^{\mathrm{Dd}}$ & $0.07^{\mathrm{Aa}}$ & $0.18^{\mathrm{Ed}}$ & $12.00^{\mathrm{Aa}}$ & $1.69^{\mathrm{Dd}}$ \\
\hline
\end{tabular}

$X_{1}$ and $X_{2}$ correspond to the independent variable. $X_{1}$ is the hot water temperature $\left({ }^{\circ} \mathrm{C}\right) ; X_{2}$ is the calcium chloride concentration (\%); ${ }^{\circ}$ Brix is the total soluble solids; $\mathrm{A}_{\mathrm{w}}$ is the water activity; $\mathrm{pH}$ is the potential hidrogenionic; TA is the titratable acidity (\%) and Vit. C is the vitamin $\mathrm{C}$ content $(\mathrm{mg} / 100 \mathrm{~g})$. Each column, means followed by the same script capital letter is not significantly different $(p<0.05)$ between hot water temperature and, the same lower case between calcium chloride concentration by Tukey test. Were used $a, b$ and $c$ for mango and $d, e$ and $f$ for banana fruits.

(b)

\begin{tabular}{cccccccccccc}
\hline Variable & \multicolumn{2}{c}{ Brix } & \multicolumn{2}{c}{ Aw } & \multicolumn{2}{c}{$\mathrm{pH}$} & \multicolumn{2}{c}{ TA } & \multicolumn{2}{c}{ Vit. C } \\
\hline Fruit & Mango & Banana & Mango & Banana & Mango & Banana & Mango & Banana & Mango & Banana \\
\hline$R^{2}$ & 0.34 & 0.18 & 0.57 & 0.57 & 0.84 & 0.64 & 0.80 & 0.64 & 0.18 & 0.80 \\
Average & 14.36 & 16.06 & 0.97 & 0.92 & 4.05 & 4.84 & 0.07 & 0.17 & 11.40 & 1.68 \\
$X_{1}$ & 0.02 & 0.48 & 0.00 & 0.01 & 0.03 & 0.18 & $-0.03^{*}$ & 0.00 & -0.13 & $-0.11^{*}$ \\
$X_{1}^{2}$ & 0.17 & -0.47 & 0.01 & 0.00 & $1.06^{*}$ & 0.62 & 0.01 & $-0.04^{*}$ & 0.29 & -0.21 \\
$X_{2}$ & -0.23 & -0.19 & -0.01 & 0.01 & -0.33 & -0.11 & 0.01 & -0.01 & -0.19 & -0.15 \\
$X_{2}^{2}$ & 0.10 & -0.39 & 0.00 & -0.04 & $0.57^{*}$ & 0.59 & 0.02 & 0.00 & 1.50 & 0.29 \\
$X_{1} X_{2}$ & 0.27 & 0.08 & -0.01 & -0.02 & -0.02 & -0.59 & -0.01 & -0.03 & 0.83 & $-0.57^{*}$ \\
\hline
\end{tabular}

${ }^{*}$ Significant effects to $95 \%$ confidence level. $X_{1}$ and $X_{2}$ correspond to the independent variable. $X_{1}$ is the hot water temperature $\left({ }^{\circ} \mathrm{C}\right) ; X_{2}$ is the calcium chloride concentration (\%); $X_{1}^{2}$ and $X_{2}^{2}$ are the variable quadratic coefficients; $X_{1} X_{2}$ is the coefficients of interaction between independent variables; $R^{2}$ is the determination coefficient; $\mathrm{A}_{\mathrm{w}}$ is the water activity; $\mathrm{pH}$ is the potential hidrogenionic; TA is the titratable acidity (\%) and Vit. C is the vitamin $\mathrm{C}$ content (mg/100g).

study, the interaction between hot water dipping and calcium chloride treatment influenced negatively $(p<0.05)$ the vitamin C content (Table 4(b)).

These results are not in agreement with those by the reference [20] report who evaluated the effects of heat treatment and calcium on postharvest storage of atemoya fruits. The total soluble solids $\left(3.5 \pm 0.11^{\circ}\right.$ Brix $)$, titratable acidity $(0.11$ $\pm 0.03), \mathrm{pH}(5.40 \pm 0.01)$ and ascorbic acid $(19.29 \pm 0.09 \mathrm{mg} / 100 \mathrm{~g})$ were not dif- 
ferent between treated and untreated fruits. Reference [37] assessing the effects of ripening acceleration methods on the proximate, biochemical and mineral compositions of Musa paradisiaca (Plantain) noted that there is significant difference in the composition of the $\mathrm{TA}, \mathrm{pH}$, reducing sugar, and vitamin $\mathrm{C}$ of the plantain between treatment $(p=0.05)$ where hot water and also, calcium carbide presented low values of TA, high values of vitamin $\mathrm{C}$ and similar values of $\mathrm{pH}$ as reported in the present study. Similar results were reported by the reference [38]. Considering the high levels of vitamin $\mathrm{C}$ in hot water and calcium chloride treated Cavendish bananas in the current study, it is concluded that the Cavendish banana fruits preserved its characteristics and are a good source of vitamin $\mathrm{C}$ and malic acid. Various studies have shown that changes in cell $\mathrm{pH}$ by altered physical conditions affect the mineral, biochemical and proximate contents of plant since the vacuolar acidity influences the formation of the various chemical forms. For instance, in fruits, the acid $\mathrm{pH}$ range of anthocyanins are predominantly present as red flavylium cation, and with rising $\mathrm{pH}$ mainly the colourless carbinol and the blue quinonoidal bases are synthesized leading to a scarlet colour.

Similar effects were documented for kiwi-fruit [39]. In pomegranate, the reference [36] also found TA increased significantly during the experiment, while the TSS content decreased gradually with addition of sodium and calcium treatment. These researchers also reported that the concentrations of $\mathrm{CaCl}_{2} \mathrm{de}$ layed the rapid oxidation of ascorbic acid.

\subsection{Models and Surface Predicted Responses}

It can be seen from Table 3(b) and Table 4(b) that the statistical models for $\mathrm{b}^{*}$, $\mathrm{pH}$ and titratable acidity were suitable for describing the Keitt mangoes experimental data. These responses were statistically affected by the independent variables $(p<0.05)$. The model presented high values of determination coefficient for a statistical model $\left(R^{2} \geq 0.80\right)$. With respect to other predicted responses, the statistical models showed lack of adjustment because $R^{2}<0.80$. Thus, only the models for $\mathrm{b}^{*}, \mathrm{pH}$ and titratable acidity are presented " $(3,4$ and 5$)$ ":

$$
\begin{gathered}
Y_{b^{*}}=20.07-1.37 X_{1}-0.18 X_{1}^{2}+0.40 X_{2}-1.27 X_{2}^{2}+2.31 X_{1} X_{2} \\
Y_{p H}=4.05+0.03 X_{1}+1.06 X_{1}^{2}-0.33 X_{2}+0.57 X_{2}^{2}-0.02 X_{1} X_{2} \\
Y_{T A}=0.07-0.03 X_{1}+0.01 X_{1}^{2}+0.01 X_{2}+0.02 X_{2}^{2}-0.01_{1} X_{2}
\end{gathered}
$$

where $X_{1}$ is the hot water temperature $\left({ }^{\circ} \mathrm{C}\right) ; X_{2}$ is the calcium chloride concentration in the solution (\%).

In a similar way for banana fruits, it can be seen from Table 2(b), Table 3(b) and Table 4(b) that the statistical models for ash, firmness and vitamin $\mathrm{C}$ content were suitable for describing the Cavendish banana fruits experimental data where the responses were statistically affected by the independent variables $(p<$ $0.05)$. The model presented high values of determination coefficient for a statistical model $\left(R^{2} \geq 0.80\right)$ and predicted responses with $R^{2}<0.80$ showed statistical 
models lack of adjustment. Thus, only the models for ash, firmness and vitamin $\mathrm{C}$ are presented "(6, 7 and 8$)$ ":

$$
\begin{gathered}
Y_{\text {ash }}=0.63+0.01 X_{1}-0.08 X_{1}^{2}+0.02 X_{2}+0.08 X_{2}^{2}-0.09 X_{1} X_{2} \\
Y_{\text {firmness }}=7.75-1.41 X_{1}+X_{1}^{2}-0.32 X_{2}-0.17 X_{2}^{2}-0.17 X_{1} X_{2} \\
Y_{\text {vitC }}=1.68-0.11 X_{1}-0.21 X_{1}^{2}-0.15 X_{2}+0.29 X_{2}^{2}-0.57 X_{1} X_{2}
\end{gathered}
$$

where $X_{1}$ is the hot water temperature $\left({ }^{\circ} \mathrm{C}\right) ; X_{2}$ is the calcium chloride concentration in the solution (\%).

The surface responses from the predicted models of Keitt mangoes $\mathrm{b}^{\star}, \mathrm{pH}$ and titratable acidity are presented in Figures 1-3, respectively. These graphics reflect the influences of two independent variables, namely, hot water temperature $\left({ }^{\circ} \mathrm{C}\right)$ and calcium chloride concentration in the solution (\%). The increase in $\mathrm{b}^{*}$ (yellowness or blueness) was observed with low or high values of hot water and calcium chloride concentration where optimal ranged from $55^{\circ} \mathrm{C}$ to $65^{\circ} \mathrm{C}$ and $0.88 \%$ to $2.5 \%$ or $45^{\circ} \mathrm{C}$ to $50^{\circ} \mathrm{C}$ and $4 \%$ to $5.12 \%$ (Figure 1 ).

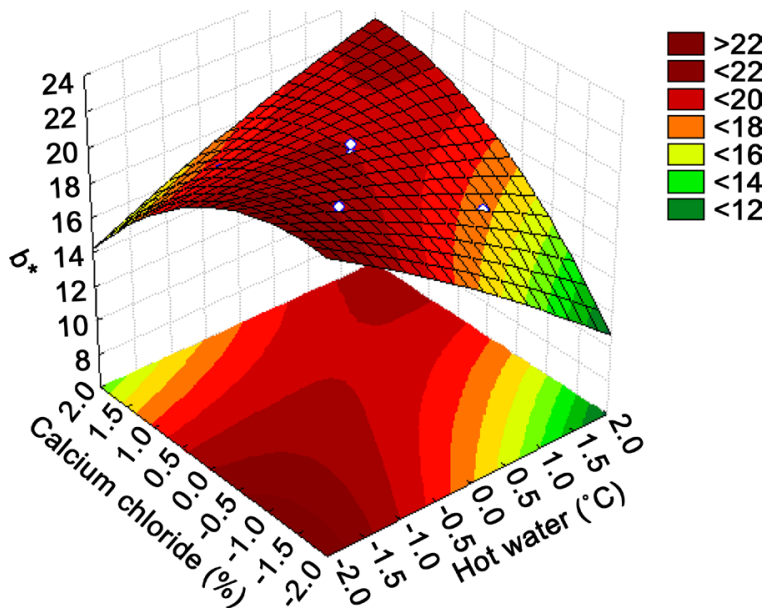

Figure 1. Surface responses from the predicted model of $b^{*}$ colour attribute of mango fruits.

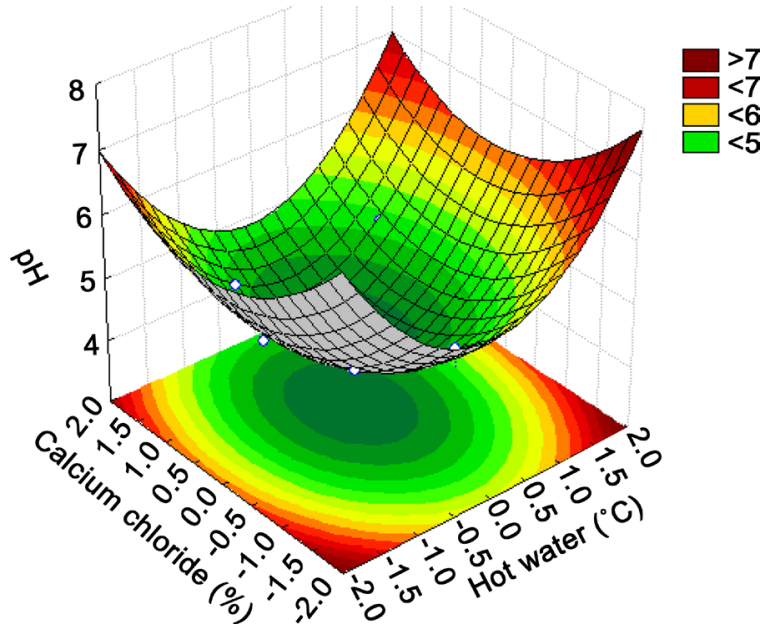

Figure 2. Surface responses from the predicted model of mango fruits $\mathrm{pH}$. 


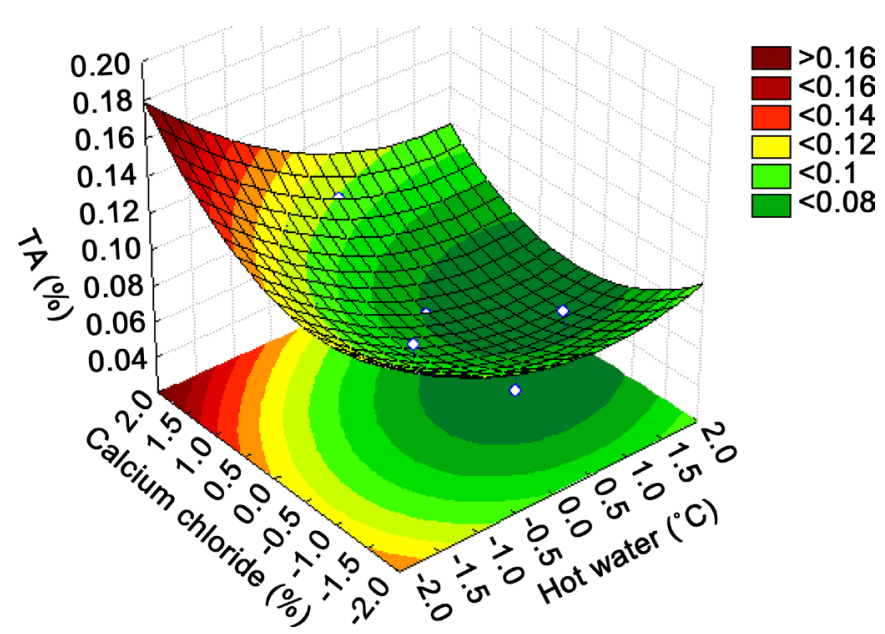

Figure 3. Surface responses from the predicted model of mango titratable acidity.

Therefore, mango fruits which were subjected to high or low hot water dipping and calcium chloride treatment $\left(40^{\circ} \mathrm{C}\right.$ to $50^{\circ} \mathrm{C}$ and $0.88 \%$ to $2.5 \%$ or $60^{\circ} \mathrm{C}$ to $65^{\circ} \mathrm{C}$ and $4 \%$ to $5.12 \%$ ) produced significantly higher peel colour score showing more yellowness than blueness which might be due to creation of a physical barrier against gas exchange from fruit surface, that may have reduced oxygen intake which is necessary for the biodegradation of chlorophyll [40].

The influences of hot water temperature $\left({ }^{\circ} \mathrm{C}\right)$ and calcium chloride concentration in the solution (\%) on mango fruits showed increased $\mathrm{pH}$ values with $X_{1}$ and $X_{2}$ extreme combination where optimal was found at central coded variables' value ranged from $52^{\circ} \mathrm{C}$ to $57^{\circ} \mathrm{C}$ and $2.5 \%$ to $3.5 \%$ (Figure 2).

Reports on both hot water and calcium chloride on the Keitt mango fruits $\mathrm{pH}$ are scarce but the reference [41] assessing the effect of hot water treatment on quality and shelf-life of Keitt mango reported increasing trend in the $\mathrm{pH}$ values while the hot water temperature and the processing time were increasing, contrasting with this work where the optimum point is know.

High mango fruits titratable acidity values were found when was combined low hot water temperature $\left({ }^{\circ} \mathrm{C}\right)$ with high calcium chloride concentration in the solution (\%) and the optimal ranged from $45^{\circ} \mathrm{C}$ to $50^{\circ} \mathrm{C}$ and $4.5 \%$ to $5.5 \%$ (Figure 3).

Reference [10] assessing the changes in Acidity, TSS, and Sugar Content at Different Storage Periods of the Postharvest Mango (Mangifera indica L.) reported high titratable acidity values (2.47\% for Khirshapat and 3.77\% for Langra varietis) of raw material but after treating with Bavistin DF the acidity was similar as reported in this work, and also, high Bavistin level presented high titratable acidity showing that regardless of variety or chemical used, mangoes fruits acidity improve with high treatment level. The results of this work are, also, in concordance with the reference [41] where low hot water temperature showed high titratable acidity.

The surface responses from the predicted models of banana fruits ash, firmness and vitamin $C$ content are presented in Figures 4-6, respectively. These 


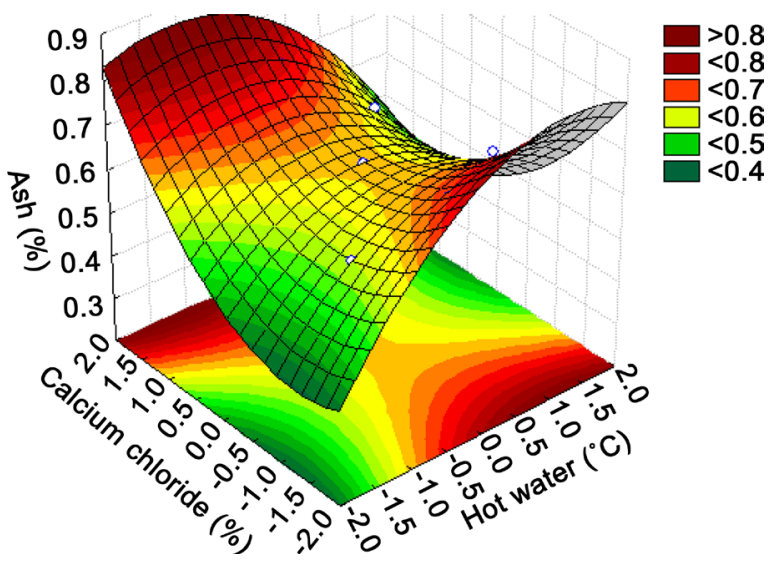

Figure 4. Surface responses from the predicted model of banana ash.

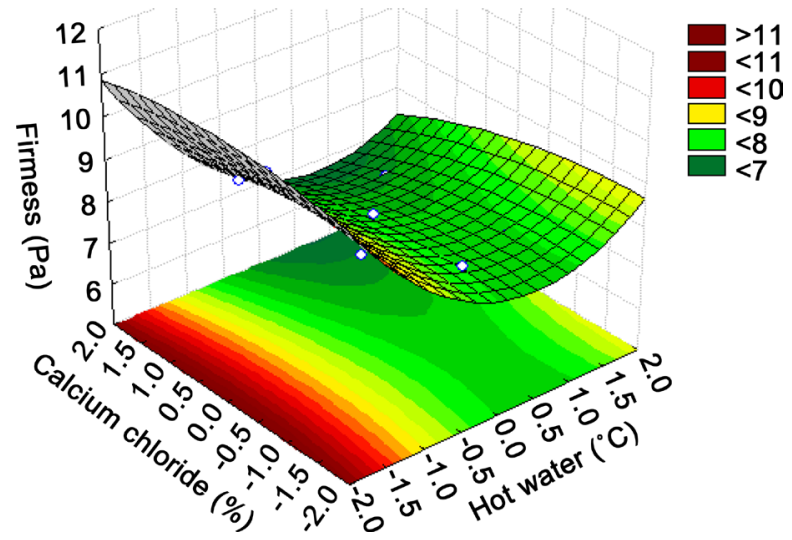

Figure 5. Surface responses from the predicted model of banana firmness.

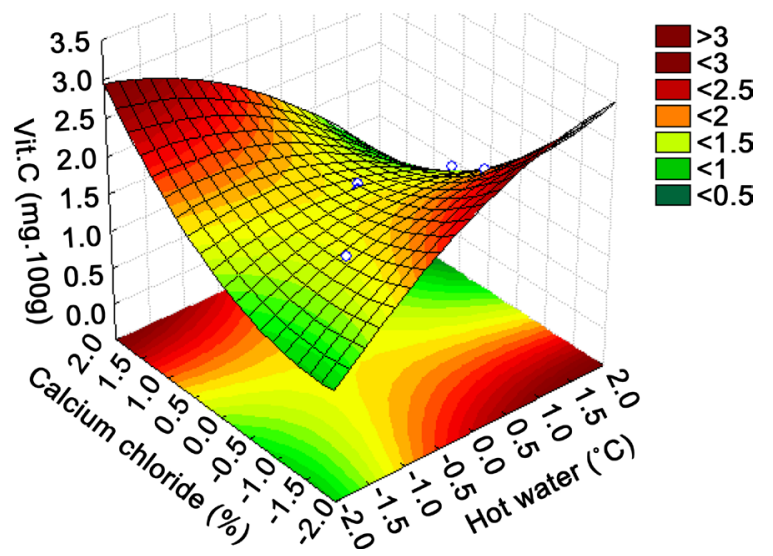

Figure 6. Surface responses from the predicted model of banana vitamin C.

graphics reflect the influences of two independent variables, namely, hot water temperature $\left({ }^{\circ} \mathrm{C}\right)$ and calcium chloride concentration in the solution (\%).

Figure 4 shows the increase in the ash content with high hot water temperature and low calcium chloride concentration or low hot water temperature and high calcium chloride concentration. The optimal conditions for banana treatment ranged from $50^{\circ} \mathrm{C}$ to $55^{\circ} \mathrm{C}$ of hot water temperature and $2 \%$ to $3 \%$ of calcium chloride concentration. Ash is considered among the chemical characteris- 
tics that define quality of a food [42] but certain treatments may be proposed to accelerate the degradation process, to prevent overall losses of minerals, or to improve the retention of critical components in food. Reference [38] used calcium carbide treatment, hot water treatment, dried plantain leaves treatment, smoked treatment and then polythene bag treatment as induced ripening methods and reported that hot water presented the lowest ash content followed by the control and calcium carbide treatment, meaning that those three treatments were not acting as ripening inductor but qualities maintainers treatments. Ash of foods is mineral contents having sodium, calcium, phosphorus and potassium, iron, and magnesium that make it valuable not only as a raw material for indigenous soap industries but also in the treatment of soils for acidity [31] [32] and [37].

The increase in firmness was observed with any values of calcium chloride concentration and hot water optimal ranged from $40^{\circ} \mathrm{C}$ to $50^{\circ} \mathrm{C}$ (Figure 5). Reference [43] reported that temperatures higher than $57^{\circ} \mathrm{C}$ for $7-9$ min caused defects on the banana peel. However, during this current study, no banana fruit peel was damaged.

Reference [44] assessing the effects of different concentration and applications of calcium on storage life and physicochemical characteristics of papaya (Carica Papaya L.) observed that calcium infiltration treatment at $2.5 \%$ significantly affected firmness followed by calcium infiltration treatments at $3.5 \%$ and $1.5 \%$, respectively compared with control treatment after storage (without calcium treatment). In this reference [44] report, the infiltration treatment at $2.5 \%$ demonstrated the best effect on maintaining fruit firmness compared with other treatments. Differently with the results obtained in this work where calcium dip treatments at $0.88 \%$ to $5.12 \%$ significantly improved maintenance of fruit firmness but maintenance of firmness tended to be higher in 3\% treated samples. The desired effect of calcium infiltration at $3 \%$ on maintaining fruit firmness may be due to the calcium binding to free carboxyl groups of polygalacturonate polymer, stabilizing and strengthening the cell walls.

A firming effect by a combination of calcium chloride dip and heat treatment has also been shown in fresh cut melons by the reference [45]. These results may indicate that the firming effect is accompanied by improved water holding capacity due to a more cross linked pectin network. Additionally, higher water holding capacity could be related to increased firmness due to higher turgor pressure which is supported by higher moisture content and hardness attributes obtained with infiltration treatment at $3 \%$.

Figure 6 shows the increase in the vitamin C content with high hot water temperature and low calcium chloride concentration or low hot water temperature and high calcium chloride concentration. The optimal preservation conditions ranged from $50^{\circ} \mathrm{C}$ to $55^{\circ} \mathrm{C}$ of hot water temperature and $2 \%$ to $3 \%$ of calcium chloride. Reference [43] treated two different varieties of banana, 'Bari Kola' and 'Sabri Cola', with six different combinations of hot water temperatures 
and times. The bananas treated with combinations of $53^{\circ} \mathrm{C}$ for $9 \min$ or $55^{\circ} \mathrm{C}$ for 7 min exhibited reduced vitamin $\mathrm{C}$ content, however, in the current work, the observations were different. Reference [46] treated apple with $0 \%$ to $4 \% \mathrm{CaCl}_{2}$ and stored the fruit at $2{ }^{\circ} \mathrm{C}$ and found that ascorbic acid content ranged between $200 \%-400 \%$ in calcium treated fruit as compared to the control (untreated). They found that $\mathrm{CaCl}_{2}$ treated fruit were firmer and had more ascorbic acid than untreated fruit results. These observations are similar to those of the current study. This increase in vitamin $\mathrm{C}$ content was reported by the references [44] for papaya treated with $\mathrm{CaCl}_{2}$, [47] on Royal Delicious Apples (Malus $\mathrm{X}$ domestica Borkh) treated with calcium sprays and postharvest hot water and [36] assessing the effects of sodium and calcium treatments on pomegranate, but the reference [43] reported decreased vitamin C content after treating banana fruit with different temperature and time, and [39] assessing the effect of hot water and calcium solution dipping on quality in kiwi-fruit observed maintenance of vitamin $\mathrm{C}$ content.

In a hot water and calcium chloride treatment, the optimum condition is the one that carries out to the higher firmness and the maintenance of ash and vitamin $\mathrm{C}$ content. For Cavendish banana fruits hot water dipping and calcium chloride treatment, the performed statistical analysis based on the CCD resulted on the following ranges: $50^{\circ} \mathrm{C}$ to $60^{\circ} \mathrm{C}$ of hot water temperature and $2 \%$ to $3 \%$ calcium chloride concentration.

\subsection{Optimization of Process Variables through the Desirability Function}

The results obtained by central composite design (CCD) showed that only the predicted models of $\mathrm{b}^{*}, \mathrm{pH}$ and mango fruits titratable acidity were adjusted to describe the experimental data. Thus, the hot water dipping and calcium chloride treatment process optimization of Keitt mango fruits, using the desirability function and considering the condition of the process that results in the higher titratable acidity, the maintenance of $\mathrm{b}^{*}$ and reducing the $\mathrm{pH}$ values, was performed.

Simultaneous evaluation of mangoes responses in total desirability profile is shown in Figure 7. By applying the desirability function, the optimal conditions of the hot water dipping and calcium chloride treatment of Keitt mango fruits are $55^{\circ} \mathrm{C}$ of hot water temperature and $3 \%$ of calcium chloride concentration. Under these conditions, $\mathrm{b}^{*}$ colour attribute is maintained, $\mathrm{pH}$ is reduced and fruit titratable acidity is maximized, which presented predicted values of $20.07 \%$, $4.05 \%$ and $0.07 \%$, respectively.

In a similar way, the results obtained by central composite design (CCD) for banana fruits showed that only the predicted models of firmness, ash and vita$\min \mathrm{C}$ were adjusted to describe the experimental data. Thus, the hot water dipping and calcium chloride treatment process optimization of Cavendish banana fruits, using the desirability function and considering the condition of the 


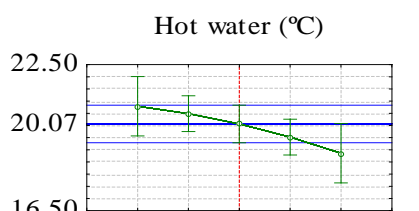

Calcium chloride (\%)
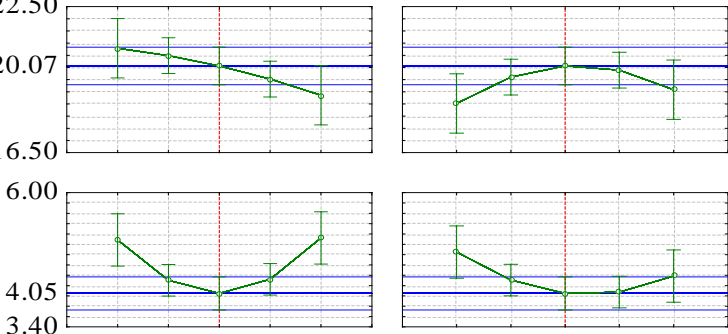

0.13
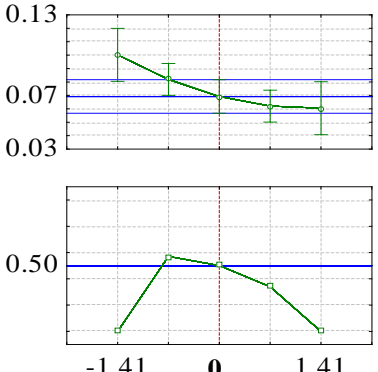
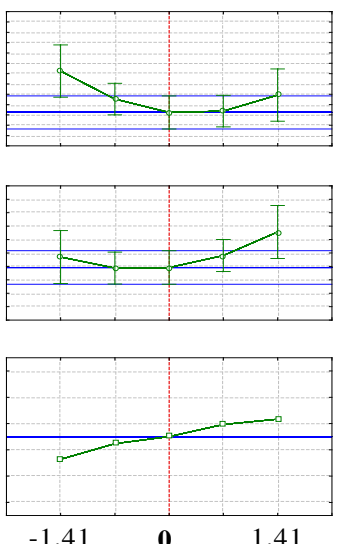

Desirability
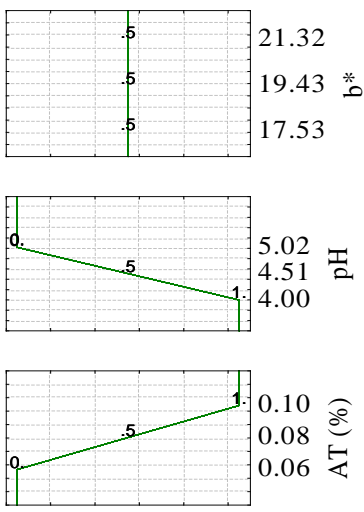

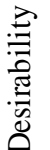

Figure 7. Profile for mango fruits predicted values and desirability.

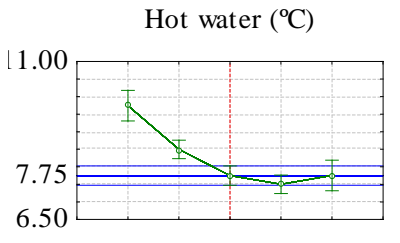

Calcium chloride (\%)

Desirability
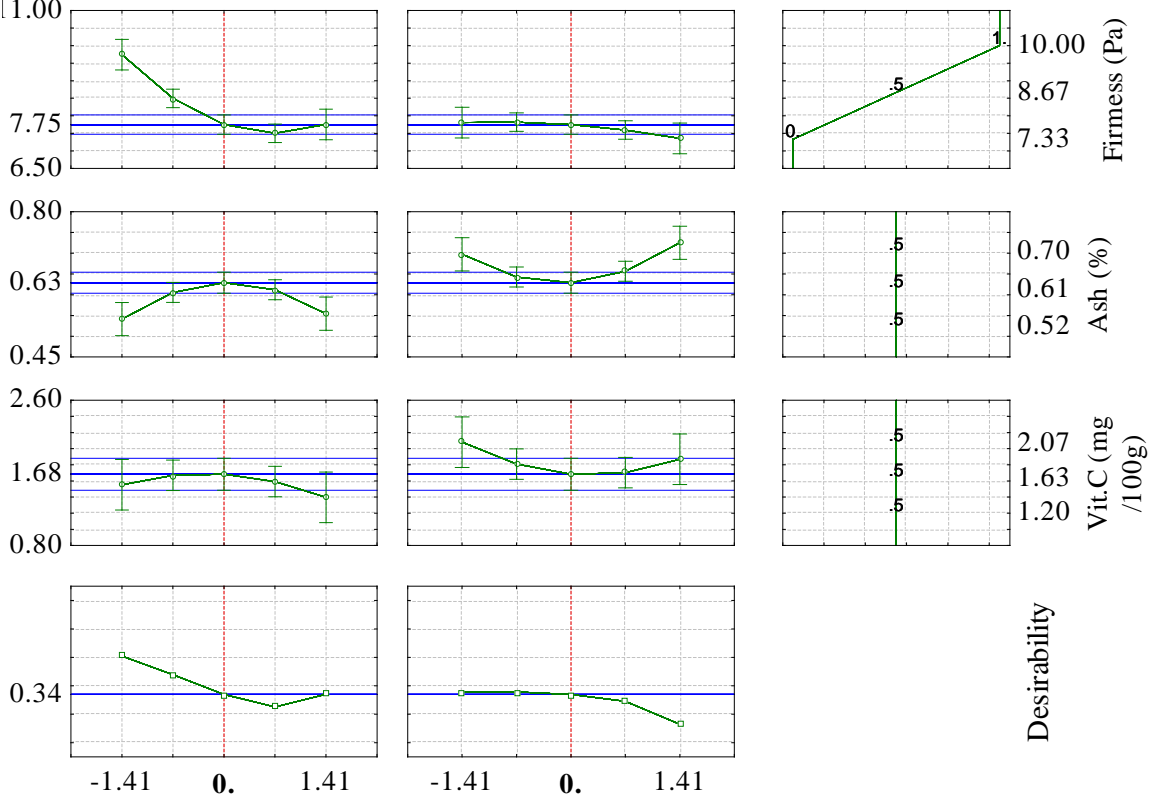

穿

Figure 8. Profile for banana fruits predicted values and desirability.

process that results in the higher firmness and the maintenance of ash and vitamin $C$ content, was performed.

Simultaneous evaluation of responses in total desirability profile is shown in Figure 8. By applying the desirability function, the optimal conditions of the hot water dipping and calcium chloride treatment of Cavendish banana fruits are, coincidentally, $55^{\circ} \mathrm{C}$ of hot water temperature and $3 \%$ of calcium chloride concentration. Under these conditions, firmness is maximized, ash and vitamin C maintained, which presented predicted values of $7.75 \mathrm{~Pa}, 0.63 \%$ and 
$1.68 \mathrm{mg} / 100 \mathrm{~g}$, respectively.

Optimal results were validated through an experiment on the optimal point. The Keitt mango fruits experimental data obtained $\left(b^{*}=20.14, \mathrm{pH}=4.01\right.$ and titratable acidity $=0.08 \%$ ) were similar to the responses predicted by the models, and the standard deviations were relatively low $(0.19,0.12$ and 0.01 , respectively), indicating that the models suit the responses.

For Cavendish banana fruit, the experimental obtained values (firmness $=7.77$ $\mathrm{Pa}$, ash $=0.62 \%$ and vitamin $\mathrm{C}=1.66 \mathrm{mg} / 100 \mathrm{~g}$ ) were, also, similar to the responses predicted by the models, and the standard deviations were relatively low $(0.03,0.03$ and 0.01 , respectively), indicating that the models suit the responses.

\section{Conclusion}

The central composite design (CCD) allowed to conclude that the optimization process of Keitt mango and Cavendish banana fruits was significantly influenced by the two variables studied namely, hot water dipping and calcium chloride treatment concentration and the methodology of simultaneous optimization using desirability function as applied in this study proved to be an efficient statistics tool in maintaining $b^{*}$ mango colour attribute, reducing fruit $\mathrm{pH}$ and maximizing fruit titratable acidity and also, maximizing the banana fruit firmness and maintaining the ash and vitamin $\mathrm{C}$ content and the optimum obtained was $55^{\circ} \mathrm{C}$ of hot water temperature and $3 \%$ of calcium chloride concentration.

\section{Acknowledgements}

The work was funded by NUFFIC through the "Enhance ISPM's Institutional Capacity to provide quality education in Agriculture (NICHE/MOZ/151) project".

\section{References}

[1] Berardini, N., Fezer, R., Conrad, J., Beifuss, U., Carle, R. and Schieber, A. (2005) Screening of Mango (Mangifera indica L.) Cultivars for their Contents of Flavonol O- and Xanthone C-Glycosides, Anthocyanins, and Pectin. Journal of Agricultural and Food Chemistry, 53, 63-70. https://doi.org/10.1021/jf0484069

[2] Sharrock, S. (2001) Diversity in the Genus Musa, Focus on Australimusa. INIBAP Annual Report 2000, 14-19.

[3] César, A. (2014) Estratégia do Governo e Oportunidades de Investimento no Agronegócio em Moçambique. [Government Strategy and Agribusiness Investment Opportunities in Mozambique.] Centro de Promoção da Agricultura (CEPAGRI) Rua da Gávea n³3, Caixa Postal nº 1772, Maputo. http://www.cepagri.gov.mz

[4] USDA (2010) National Nutrient Database for Standard Reference, SR-23, Fruit Reports-09, USDA, Mango, Raw, 449.

[5] Liu, R.H. (2003) Health Benefits of Fruit and Vegetables Are from Additive and Synergistic Combinations of Phytochemicals. American Society for Clinical Nutrition, 78, 3-6.

[6] Schreiner, M. and Huyskens-Keil, S. (2006) Phytochemicals in Fruit and Vegetables: Health Promotion and Postharvest Elicitors. Critical Reviews in Plant Sciences, 25, 
267-278. https://doi.org/10.1080/07352680600671661

[7] UNIDO (2004) Small-Scale Fruit and Vegetable Processing and Products: Production Methods, Equipment and Quality Assurance Practices. United Nations Industrial Development Organization (UNIDO). UNIDO Technology Manual, Vienna, $107 \mathrm{p}$.

[8] Jha, S.N., Jaiswal, P., Narsaiah, K., Kaur, P.P., Singh, A.K. and Kumar, R. (2013) Textural Properties of Mango Cultivars during Ripening. Journal of Food Science and Technology, 50, 1047-1057. https://doi.org/10.1007/s13197-011-0431-Z

[9] Shahir, S. and Visvanathan, R. (2014) Maturity Measurement of Mango and Banana as Related to Ripening. Trends in Biosciences, 7, 741-744.

[10] Islam, Md.K., Khan, M.Z.H., Sarkar, M.A.R., Absar, N. and Sarkar, S.K. (2013) Changes in Acidity, TSS, and Sugar Content at Different Storage Periods of the Postharvest Mango (Mangifera indica L.) Influenced by Bavistin DF. International Journal of Food Science, 2013, Article ID: 939385, 8 p.

[11] Tian, S., Liu, J., Zhang, C. and Meng, X. (2010) Fresh Produce 4 (Special Issue 1), 49-55. Global Science Books.

[12] Ahmed, O.K. and Ahmed, S.E.T. (2014) Determination of Optimum Maturity Index of Mango Fruits (Mangifera indica, L.) in Darfur. Agriculture and Biology Journal of North America, 5, 97-103.

[13] Tapre, A.R. and Jain, R.K. (2012) Study of Advanced Maturity Stages of Banana. International Journal of Advanced Engineering Research and Studies, 1, 272-274.

[14] Amin, M.N., Hossain, M.M., Rahim, M.A. and Uddin, M.B. (2015) Determination of Optimum Maturity Stage of Banana. Bangladesh Journal of Agricultural Research, 40, 189-204. https://doi.org/10.3329/bjar.v40i2.24557

[15] Wang, C.Y. (1990) Alleviation of Chilling Injury of Horticultural Crops. In: C.Y. Wang (Editor), Chilling Injury of Horticultural Crops. CRC Press, Boca Raton, 269-280.

[16] Porat, R., Pavencello, D., Peretz, J., Ben-Yohoshua, S. and Lurie, S. (2000) Effects of Various Heat Treatments on the Induction of Cold Tolerance and on the Post Harvest Qualities of 'Star Ruby' Grapefruit. Postharvest Biology and Technology 18, 159-165. https://doi.org/10.1016/S0925-5214(99)00075-7

[17] McDonald, R.E., McCollum, T.G. and Baldwin, E.A. (1999) Temperature of Water Treatments Influences Tomato Fruit Quality Following Low Temperature Storage. Postharvest Biology and Technology, 16, 147-155. https://doi.org/10.1016/S0925-5214(99)00008-3

[18] Biggs, M.S., Woodson, W.R. and Handa, A.K. (1988) Biochemical Basis of High Temperature Inhibition of Ethylene Biosynthesis in Ripening Tomato Fruit. Physiologia Plantarum, 72, 572-578. https://doi.org/10.1111/j.1399-3054.1988.tb09167.x

[19] Lum, M.S. and Norazira, M.A. (2011) Effects of Hot Water, Submergence Time and Storage Duration on Quality of Dragon Fruit (Hylocereus polyrhizus). Journal of Agricultural Science, 3, 58-63. https://doi.org/10.5539/jas.v3n1p146

[20] Torres, L.M.A.R., Silva, M., Guaglianoni, D.G. and Neves, V.A. (2009) Effects of Heat Treatment and Calcium on Postharvest Storage of Atemoya Fruits. Alimentos e Nutrição, 20, 359-367.

[21] Yuen, C.M.C., Caffin, N. and Boonyakiat, D. (1994) Effect of Calcium Infiltration on Ripening of Avocados at Different Maturities. Australian Journal of Experimental Agriculture, 34, 123-126. https://doi.org/10.1071/EA9940123

[22] Hernández-Muñoz, P. (2006) Effect of Calcium Dips and Chitosan Coatings on 
Postharvest Life of Strawberries (Fragaria x ananassa). Postharvest Biology and Technology, 39, 247-253. https://doi.org/10.1016/j.postharvbio.2005.11.006

[23] AOAC (2005) Association of Official and Analytical Chemists. Helrich, K., Ed., 17th Edition, Arlington, Virgina.

[24] Davies, M.B., Austin, J. and Partridge, D.A. (1991) Vitamin C: Its Chemistry and Biochemistry. Royal Society of Chemistry, Cambridge.

[25] Corrêa, J.L.G., Pereira, L.M., Vieira, G. and Hubinger, M.D. (2010) Mass Transfer Kinetics of Pulsed Vacuum Osmotic Dehydration of Guavas. Journal of Food Engineering, 96, 498-504. https://doi.org/10.1016/j.jfoodeng.2009.08.032

[26] Arballo, J.R., Bambicha, R.R., Campanone, L.A., Agnelli, M.E. and Mascheroni, R.H. (2012) Mass Transfer Kinetics and Regressional-Desirability Optimisation during Osmotic Dehydration of Pumpkin, Kiwi and Pear. International Journal of Food Science and Technology, 47, 306-314. https://doi.org/10.1111/j.1365-2621.2011.02840.x

[27] Corrêa, J.L.G., Ernesto, D.B., Alves, J.G.L.F. and Andrade, R.S. (2014) Optimisation of Vacuum Pulse Osmotic Dehydration of Blanched Pumpkin. International Journal of Food Science and Technology, 49, 2008-2014.

https://doi.org/10.1111/ijfs.12502

[28] Rodrigues, M. and Iemma, A. (2012) Experimental Design and Process Optimization; Casa do Espírito Amigo Fraternidade Fé e Amor, Campinas.

[29] Derringer, G.C. and Suich, R. (1980) Simultaneous Optimization of Several Response Variables. Journal of Quality Technology, 12, 214-219.

[30] Lamikanra, O. and Watson, M.A. (2007) Mild Heat and Calcium Treatment Effects on Fresh-Cut Cantaloupe Melon during Storage. Food Chemistry, 102, 1383-1388. https://doi.org/10.1016/j.foodchem.2006.05.060

[31] Iroka, C.F., Akachukwu, E.E., Adimonyemma, R.N., Okereke, N.C. and Nwogiji, C.O. (2016) Effects of Induced Ripening on the Proximate, Biochemical and Mineral Compositions of Carica papaya (Pawpaw Fruit). European Journal of Medicinal Plants, 15, 1-10. https://doi.org/10.9734/EJMP/2016/26260

[32] Auta, S.A. and Kumurya, A.S. (2015) Comparative Proximate, Mineral Elements and Anti-Nutrients Composition between Musa sapientum (Banana) and Musa paradisiaca (Plantain) Pulp Flour. Sky Journal of Biochemistry Research, 4, 25-30.

[33] Ngamchuachit, P., Sivertsen, H.K., Mitcham, E.J. and Barrett, D.M. (2014) Effectiveness of Calcium Chloride and Calcium Lactate on Maintenance of Textural and Sensory Qualities of Fresh-Cut Mangoes. Journal of Food Science, 00, 11-20.

[34] Joyce, D.C., Shorter, A.J. and Hockings, P.D. (2001) Mango Fruit Calcium Levels and the Effect of Postharvest Calcium Infiltration at Different Maturities. Scientia Horticulturae, 91, 81-99. https://doi.org/10.1016/S0304-4238(01)00247-3

[35] Ioannou, I. and Ghoul, M. (2013) Prevention of Enzymatic Browning in Fruit and Vegetables. European Scientific Journal, 9, 57-81.

[36] Kazemi, F., Jafararpoor, M. and Golparvar, A. (2013) Effects of Sodium and Calcium Treatments on the Shelf Life and Quality of Pomegranate. International Journal of Farming and Allied Sciences, 2, 1375-1378.

[37] Izundu, I.A., Chukwuma, O.M., Adimonyemma, N.R. Akachukwu, E.E. and Iroka, C.F. (2016) Effects of Ripening Acceleration Methods on the Proximate, Biochemical and Mineral Compositions of Musa paradisiaca (Plantain). Ewemen Journal of Herbal Chemistry \& Pharmacology Research, 2, 26-33.

[38] Maureen, C.O., Chisom, I.F., Esther, A.E., Ruffina, A.N. and Ann, M.O. (2016) A 
Study of the Effects of Induced Ripening on the Proximate, Biochemical and Mineral Compositions of Musa sapientum (Banana). International Journal of Food Science and Nutrition, 1, 15-20.

[39] Shahkoomahally, S. and Ramezanian, A. (2013) The Effect of Hot Water and Calcium Solution Dipping on Quality in Kiwifruit during Storage. American-Eurasian Journal of Agricultural \& Environmental Sciences, 13, 1351-1356.

[40] Anwar, R. and Malik, A.U. (2007) Hot Water Treatment Affects Ripening Quality and Storage Life of Mango (Mangifera indica L.). Pakistan Journal of Agricultural Sciences, 44, 5-14.

[41] Kumah, P., Appiah, F. and Opoku-Debrah, J.K. (2011) Effect of Hot Water Treatment on Quality and Shelf-Life of Keitt Mango. Agriculture and Biology Journal of North America, 2, 806-817. https://doi.org/10.5251/abjna.2011.2.5.806.817

[42] Osagie, A.U. and Eka, O.U. (1998) Nutritional Quality of Plant Foods. Postharvest Research Unit, University of Benin, Benin City.

[43] Amin, M.N. and Hossain, M.M. (2013) Reduction of Postharvest Loss and Prolong the Shelf -Life of Banana through Hot Water Treatment. Journal of Chemical Engineering, 27, 42-47. https://doi.org/10.3329/jce.v27i1.15857

[44] Mahmud, T.M.M., Al Eryani-Raqeeb, A., Syed Omar, S.R., Mohamed Zaki, A.R and Al Eryani, A.R. (2008) Effects of Different Concentrations and Applications of Calcium on Storage Life and Physicochemical Characteristics of Papaya (Carica Papaya L.). American Journal of Agricultural and Biological Sciences, 3, 526-533. https://doi.org/10.3844/ajabssp.2008.526.533

[45] Luna-Guzman, I., Cantwell, M. and Barrett, D.M. (1999) Fresh Cut Cantaloupe: Effects of $\mathrm{Cacl}_{2}$ Dips and Heat Treatments on Firmness and Metabolic Activity. Postharvest Biology and Technology, 17, 201-213. https://doi.org/10.1016/S0925-5214(99)00048-4

[46] Laufmann, J.E. and Sams, C.E. (1989) The Effect of Postharvest Calcium Treatment on Polyphenol Oxidase and Peroxidase Activity in Golden Delicious Apples. Hort Science, 24, 753-754.

[47] Sharma, R.R., Singh, D. and Pal, R.K. (2013) Synergistic Influence of Pre-Harvest Calcium Sprays and Postharvest Hot Water Treatment on Fruit Firmness, Decay, Bitter Pit Incidence and Postharvest Quality of Royal Delicious Apples (Malus $X$ domestica Borkh). American Journal of Plant Sciences, 4, 153-159.

https://doi.org/10.4236/ajps.2013.41020 